Article

\title{
Spatial and Temporal Trends of Burnt Area in Angola: Implications for Natural Vegetation and Protected Area Management
}

\author{
Silvia Catarino ${ }^{1,2, *}$, Maria Manuel Romeiras ${ }^{1,3, *}$, Rui Figueira ${ }^{1,4}\left(\mathbb{D}\right.$, Valentine Aubard ${ }^{2} \oplus$, \\ João M. N. Silva ${ }^{2}$ (1) and José M. C. Pereira ${ }^{2}$ \\ 1 Linking Landscape, Environment, Agriculture and Food (LEAF), School of Agriculture, University of Lisbon, \\ Tapada da Ajuda, 1349-017 Lisbon, Portugal; ruifigueira@isa.ulisboa.pt \\ 2 Forest Research Centre (CEF), School of Agriculture, University of Lisbon, Tapada da Ajuda, \\ 1349-017 Lisbon, Portugal; vaubard@isa.ulisboa.pt (V.A.); joaosilva@isa.ulisboa.pt (J.M.N.S.); \\ jmcpereira@isa.ulisboa.pt (J.M.C.P.) \\ 3 Centre for Ecology, Evolution and Environmental Changes (cE3c), Faculty of Sciences, University of Lisbon, \\ 1749-016 Lisbon, Portugal \\ 4 Research Centre in Biodiversity and Genetic Resources (CIBIO/InBIO), School of Agriculture, University of \\ Lisbon, Tapada da Ajuda, 1349-017 Lisbon, Portugal \\ * Correspondence: scatarino@isa.ulisboa.pt (S.C.); mmromeiras@isa.ulisboa.pt (M.M.R.)
}

Received: 18 June 2020; Accepted: 5 August 2020; Published: 9 August 2020

\begin{abstract}
Fire is a key driver of natural ecosystems in Africa. However, human activity and climate change have altered fire frequency and severity, with negative consequences for biodiversity conservation. Angola ranks among the countries with the highest fire activity in sub-Saharan Africa. In this study, we investigated the spatial and temporal trends of the annual burnt area in Angola, from 2001 to 2019, and their association with terrestrial ecoregions, land cover, and protected areas. Based on satellite imagery, we analyzed the presence of significant trends in burnt area, applying the contextual Mann-Kendall test and the Theil-Sen slope estimator. Data on burnt areas were obtained from the moderate-resolution imaging spectroradiometer (MODIS) burnt area product and the analyses were processed in TerrSet. Our results showed that ca. 30\% of the country's area burned every year. The highest percentage of annual burnt area was found in northeast and southeast Angola, which showed large clusters of decreasing trends of burnt area. The clusters of increasing trends were found mainly in central Angola, associated with savannas and grasslands of Angolan Miombo woodlands. The protected areas of Cameia, Luengue-Luiana, and Mavinga exhibited large areas of decreasing trends of burnt area. Conversely, $23 \%$ of the Bicuar National Park was included in clusters of increasing trends. Distinct patterns of land cover were found in areas of significant trends, where the clusters of increasing trends showed a higher fraction of forest cover $(80 \%)$ than the clusters of decreasing trends (55\%). The documentation of burnt area trends was very important in tropical regions, since it helped define conservation priorities and management strategies, allowing more effective management of forests and fires in countries with few human and financial resources.
\end{abstract}

Keywords: wildfires; MODIS burnt area product; WWF ecoregions; land cover; Miombo woodlands; biodiversity conservation; sub-Saharan Africa

\section{Introduction}

Fire is considered a key driver of biodiversity [1], playing an important role in the structure and distribution of ecosystems and biochemical cycles [2]. It determines the distribution, ecology, and maintenance of African savannas and grasslands [3-5]. Over the last million years, the frequent 
occurrence of fires in Africa promoted the evolution of a more fire-tolerant and dependent flora [6]; without fire, large areas of savannas could develop into closed woodlands [4].

In southern Africa, however, the severity of fires caused by human activity is increasing [7], with negative consequences for biodiversity conservation and climate change. Approximately $70 \%$ of the global burnt area and $50 \%$ of fire-related carbon emissions are produced in Africa [8,9]. Uncontrolled fires can greatly damage residential zones, agricultural areas, and forests that are not adapted to fire, contributing to deforestation in many African countries, and producing gas emissions with harmful effects on human health and global climate [10-12]. In Africa, wildfires were identified as the main driver of forest degradation in remote areas of forests, which are more likely affected by recurring fires than by timber extraction [13]. On the other hand, fires are also used in the traditional slash-and-burn agriculture, which consists of cutting trees and woody plants from an area and then burning biomass, resulting in nutrient-rich ash that makes the soil more fertile for agriculture and grazing [13,14]. Savanna fires start by natural causes, mainly lightning, and human intervention, but the relative share of anthropogenic fires is quickly increasing in Africa. In savannas of West Africa, human activity is the most important factor causing fires [11].

The size of burnt areas varies greatly across countries and depends on rainfall seasonality, human activity, and available fuel $[15,16]$. The fire regime is strongly related to the land use practices and rural populations greatly influence the extent of fires and the annual area burnt $[16,17]$.

Historically, humans have used fire to clean the land [16]. The rural population, which continues to grow in many African countries, frequently uses fire to promote grass growth for cattle to eliminate agricultural residues after harvests and to clear agricultural lands [16]. Moreover, wood and charcoal are the main sources of energy for cooking and heating in rural communities, their use enhancing the exploitation of natural resources and deforestation [11]. An increase in biomass burning causes local drying of the atmosphere, reducing rainfall in the region [12].

According to Archibald et al. [18], Angola, Zambia, and Mozambique are the countries with the most fire activity in southern Africa. In these countries, where the fires are mainly grass-fueled surface and closely related with areas of grass vegetation, such as savannas, grassland, forest and transitions, approximately $50 \%$ of the land area was affected by fire between 2001 and 2008, and a large part of it was burnt more than four times during this period [18].

Angola encompasses a great diversity of habitats from desert to tropical rain forests but is dominated by grasslands, savannas, and scrublands [19]. In total, 15 different ecoregions of the global ecoregions map of World Wildlife Fund (WWF) are present in Angola [20], of which the most widespread are the Miombo woodlands of the central plateau, and the western Congolian forest-savanna mosaics in the north [21]. Other important but less extensive ecoregions found in this country are the Atlantic Equatorial coastal forests in Cabinda and the mopane woodlands and the Namibian savanna woodlands in the southwest [20]. In this country, fires are generally classified as surface fires, occurring mainly during the dry season between late April and November [22,23]. Northern regions and central highlands burn considerably earlier than southern zones, when the grass fuel contains higher moisture, resulting in cooler, less intense fires that are less damaging to vegetation than the later and hotter fires in southern Angola [15,23].

Over the last years, intense fires are becoming more frequent in Angola [23]. Very dry seasons and consecutive years of drought with low-humidity conditions promote an increase in the occurrence and intensity of fire [24]. Moreover, droughts have led to significant food insecurity, reducing many populations to subsistence conditions and increasing use of fire to clear hunting zones and preparing new ones for cultivation [14]. Recent studies [23,25] show that Angolan forests have been strongly affected by severe and recurrent fires. Although a single fire has no strong effect on tree composition, the damage caused by recurrent fires in the late dry season can cause high tree mortality [26]. For woodlands in south Africa, a period of at least 5 years without fire is necessary for the successful reestablishment of some tree species [27,28], but such an interval rarely happens in Angolan savannas [17,29]. 
Currently, deforestation continues to increase in Angola, where one of the highest rates of tree cover loss in sub-Saharan Africa occurs [30-32]. Most of the native trees are under severe pressure due to logging, wood harvesting and charcoal production $[21,33,34]$, as well as fire-related human and climate factors [35-37]. With southern Angola expected to become drier and warmer as a consequence of climate changes, fire frequency is likely to increase and the conservation of Angolan forests and savannas is urgently needed $[38,39]$. Effective biodiversity conservation requires that fire plays a natural role in ecosystems without representing a threat to ecosystems or human well-being [40].

The current forest degradation caused by fires is difficult to quantify, requiring a comparison of repeated measurements over time [26]. Over the last two decades, remote sensing has become a very useful technique to map burnt areas at regional and global scales, providing a comprehensive view of landscape patterns of fire (e.g., [10,18,29,41,42]). Mapping burnt areas over the years is crucial for resource managers to understand fire impacts on habitats, wildlife, and human settlements, particularly in the context of global climate change [11]. The moderate-resolution imaging spectroradiometer (MODIS) has been extensively used for the study of fire and burnt areas, including in southern Africa [18,24,25]. For instance, Archibald et al. [18] analyzed fire regimes in southern Africa, based on fire frequency, fire seasonality, fire radiative power, and fire size, as well as their relationship to human activities. Mishra et al. [24] examined how variations in burned area and fire frequency were determined by rainfall, vegetation morphology, and land use in the semiarid savanna of Botswana. Schneibel et al. [25] studied the role of fire in forest degradation processes in south-central Angola. However, the study of spatial and temporal trends of burnt area and the determination of its magnitude have never been carried out in Angola. MODIS derived burnt-area product (MCD64A1) is based on changes in surface reflectance over time and includes per-pixel burnt area and quality information about recent fires $[43,44]$. It is available as monthly global maps, with good detection of small burns, low temporal uncertainty, and a small extent of unmapped areas $[18,44,45]$.

The main goal of this study is to analyze spatial and temporal trends of the area annually burnt in Angola between 2001 and 2019, and how these trends affected the conservation goals of the country, i.e., the sustainable use of natural resources, the recovery of its biodiversity, and the rehabilitation of its protected areas after almost 30 year of war [14]. Specifically, we aimed to: (i) map fire incidence in Angola between 2001 and 2019; (ii) detect and analyze positive and negative trends in the annual burnt area; and (iii) analyze the association between the detected trends and the Angolan ecoregions, protected areas, and land cover classes. Our results will provide new data and useful information for the sustainable fire management and conservation of Angolan ecosystems.

\section{Materials and Methods}

\subsection{Study Area}

With ca. 1,246,700 km², the Republic of Angola is the largest country in southern Africa. It is located between $4^{\circ} 22^{\prime} \mathrm{S}$ and $18^{\circ} 02^{\prime} \mathrm{S}$, and $11^{\circ} 41^{\prime} \mathrm{E}$ and $24^{\circ} 05^{\prime} \mathrm{E}$, and is organized into 18 provinces (Figure 1). The mean annual rainfall varies between ca. $50 \mathrm{~mm}$ in Namib and more than $1500 \mathrm{~mm}$ in Lunda Norte [46]. A very diverse climate and topography originated high species richness and habitat heterogeneity. In total, 15 ecoregions are recognized in Angola [20] (Figure S1), including deserts, savannas, grasslands, tropical forests, and mangroves. The current system of protected areas includes 14 areas (Figure 1), covering about $13 \%$ of the country [47,48].

With a population of over 26 million people and an annual growth rate of $3.3 \%$ according to the 2014 population census [49], this country struggles with food scarcity, poor medical support, and lack of infrastructures [25]. Approximately 37\% of the population lives in rural areas and depends on agriculture for food and financial income $[49,50]$. The expansion of agricultural and urban areas and the demand for agricultural land are important causes of anthropogenic fire and deforestation [34,51]. 


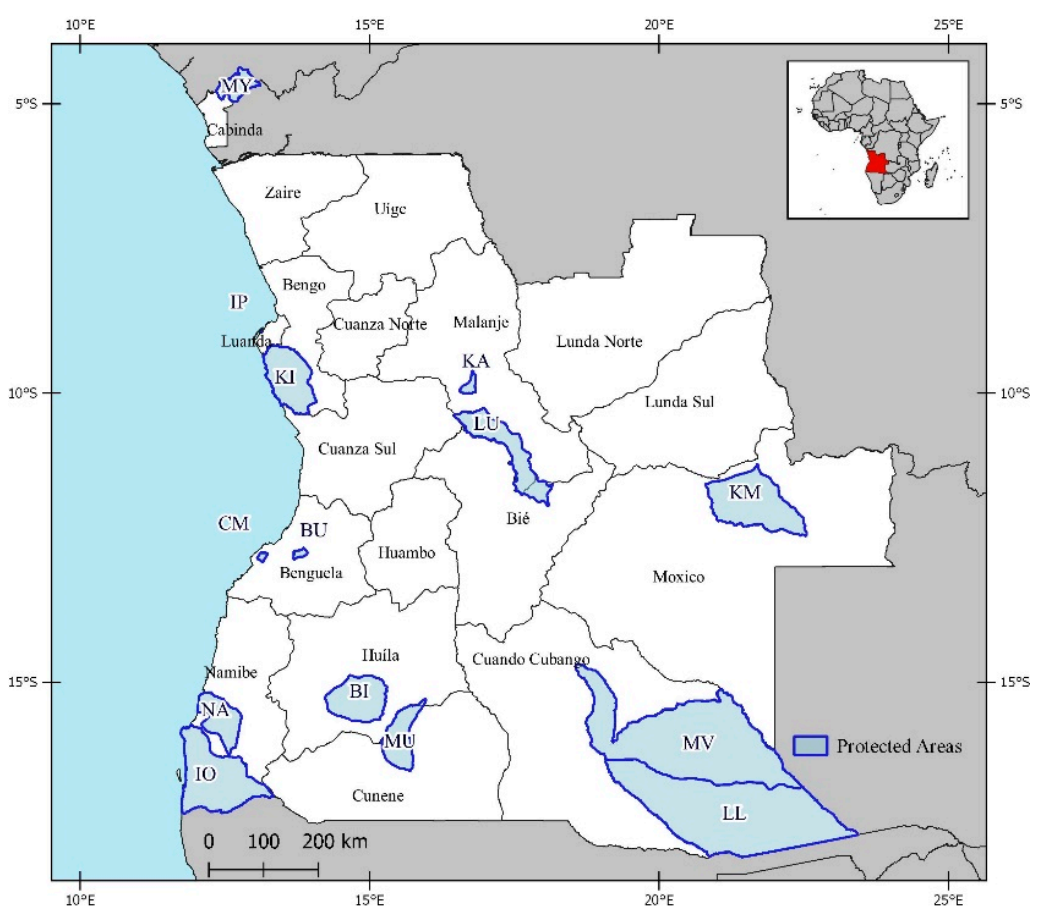

Figure 1. Study area, with the 18 provinces of Angola and the protected areas system: BI, Bicuar; BU, Búfalo; KA, Cangandala; CM, Chimalavera; IO, Iona; IP, Ilheu dos Pássaros; KM, Cameia; KI, Quiçama; LL, Luengue-Luiana; LU, Luando; MV, Mavinga; MU, Mupa; MY, Maiombe; NA, Namibe.

\subsection{Burnt Area Data, Trend Estimation, and Testing}

Data on burnt areas in Angola were obtained from the MODIS burnt area product MCD64A1 v.006 [52] and downloaded using the Google Earth Engine platform. These data are produced from MODIS Terra and Aqua daily surface reflectance products at $500 \mathrm{~m}$ resolution [52-54]. Based on the daily surface reflectance, the algorithm identifies rapid changes to detect burning events and maps their spatial extent $[52,54]$. The algorithm uses a burn sensitive vegetation index derived from MODIS shortwave infrared atmospherically corrected surface reflectance to create thresholds that are applied to composite imagery data and then spatial and temporal active-fire information is used to estimate probabilistic thresholds suitable to classify individual grid cells as burnt or unburnt $[44,52]$.

MODIS Terra and Aqua satellites were launched at different times. While the Terra sensor has been collecting data since February 2000, the Aqua sensor has been collecting data since June 2002 [55]. As the post-fire signal is persistent and the product of the burnt area is not very sensitive to the time of satellite passage [56], losing little information with just one sensor, we used monthly data from January 2001 to December 2019.

To analyze the mean annual fraction of the burnt area and the number of years of burning, we summed the data for the 12 months of each year (January to December) and resizes the resulting maps to a $5 \mathrm{~km}$ resolution grid using QGIS v.3.4.4 software [57]. Each cell was reclassified with the percentage of area burned and the number of years in which it was burned.

The analysis of the spatial and temporal trends of the burnt area was processed in TerrSet v.18.31 [58]. To avoid sequential correlation in time series (i.e., the lack of independence between observations), we applied the Durbin-Watson serial correlation test [59-61] and the pre-whitening procedure proposed by Wang and Swail [62], which maintains the same trend as the original series, but without serial correlation.

To identify significant trends, we applied the Mann-Kendall test $[63,64]$ and the contextual Mann-Kendall test [65]. The Mann-Kendall test is a nonparametric test of trend monotonicity and a common approach in studies of environmental time series $[61,65,66]$. The contextual Mann-Kendall test, proposed by Neeti and Eastman [65], is a modified version of the Mann-Kendall test that includes 
geographical contextual information, i.e., neighboring cells are involved in the determination of trends, allowing the detection of homogeneous regions with similar trends. The contextual analysis imparts greater confidence to the identified trends [61].

Then, the Theil-Sen slope estimator was applied to determine the rate of burnt area change in each cell with significant trends $[67,68]$. This non-parametric technique is robust against outliers and provides an indicator of change over time [66]. It is defined as the median of the slopes calculated between observations in all pair-wise time steps and is suitable for application to time series with large annual variations, such as those concerning annual burnt area [61]. An increasing trend is indicated by a positive $Z$ value, while a decreasing one is indicated by a negative $Z$ value.

\subsection{WWF Ecoregions, Protected Areas, and Land Cover Data}

Ecological conditions, changes in land use, and population dynamics are important drivers of fire occurrence over time. To analyze the association between these factors and the trends of the burnt areas, we compared the maps of burnt area trends with the WWF ecoregions (Figure 2a) [20], the Angolan system of protected areas [47], and land cover time-series maps (Figure 2b) [69,70].

WWF terrestrial ecoregions represent the high variability of biogeographic diversity and ecological conditions (see Figure 2a) [20,71-73]. This map was produced at a global scale and reflects the regionalization of the Earth's terrestrial biodiversity, defining units that contain a distinct assemblage of natural communities sharing a large majority of species, dynamics, and environmental conditions [20]. WWF ecoregions has been used as a basis for studies on biotic diversity and conservation in Angola [19,21,74].

Maps concerning the Angolan system of protected areas were downloaded from the World Database of Protected Areas [75]. The present extent of Luengue-Luiana and Mavinga national parks was not updated in WDPA, so it was vectorized based on published Angolan legislation (Diário da República de Angola, law 38/11 29 December 2011, p. 6340).

Land cover data were obtained from the European Space Agency (ESA) Climate Change Initiative Land Cover (CCI-LC) project [76] which produced annual land cover maps for 1992-2015 (version 2.0.7) and 2016-2018 (version 2.1.1), combining remote sensing products and ground observations [69,70]. These maps provide data describing the land surface at $300 \mathrm{~m}$ resolution, divided into 22 classes (see Figure 2b). To understand changes in land cover over time, we used the most recent land cover data available (2018) and data collected every four years (2002, 2006, 2010, and 2014). Finally, the maps of burnt area and significant trends were spatially intersected with the WWF ecoregions, protected areas, and land cover maps using QGIS v.3.4.4 software [57]. 


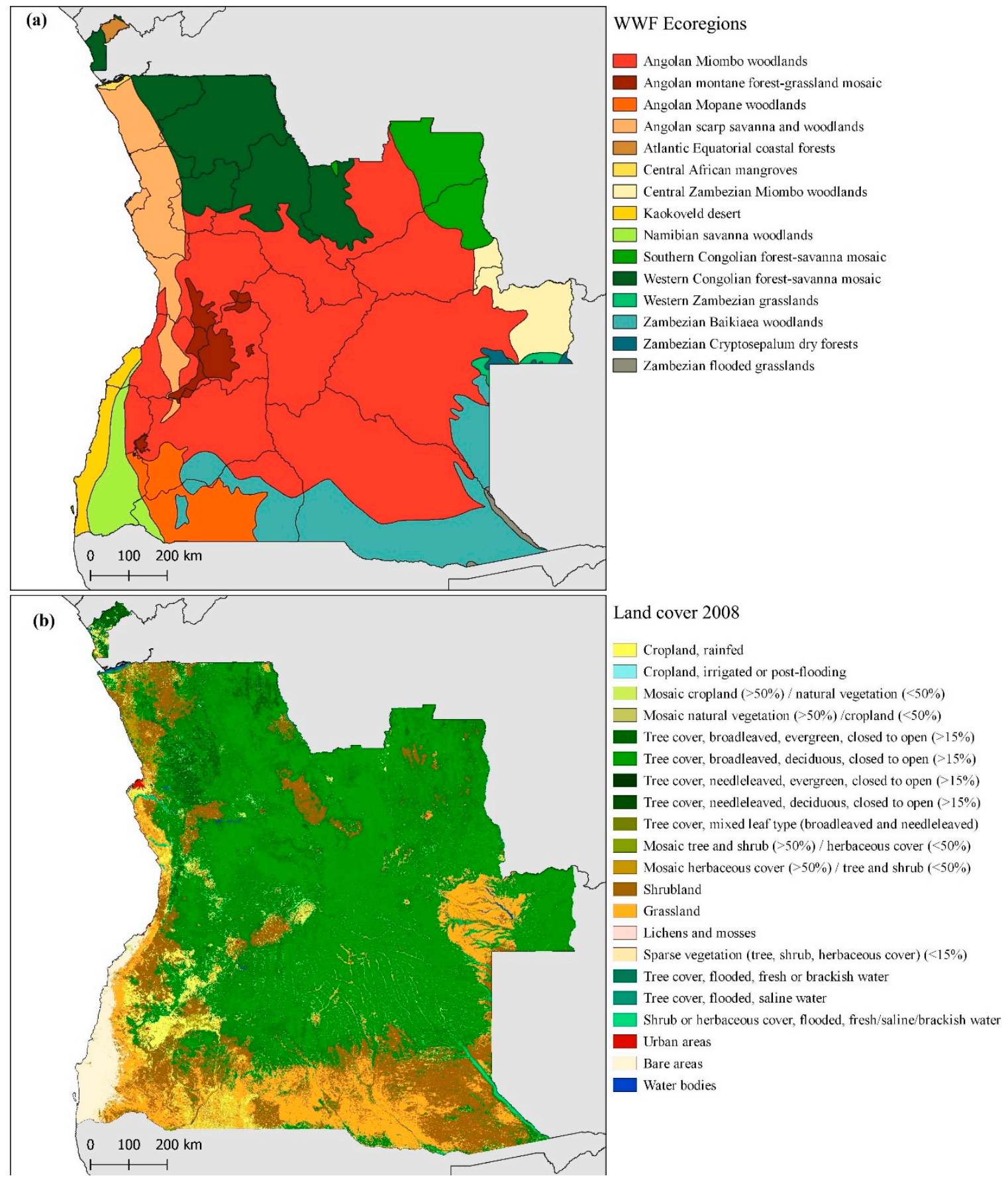

Figure 2. World Wildlife Fund (WWF) ecoregions and land cover map of Angola: (a) WWF ecoregions occurring in Angola [20]. The black lines represent the boundaries of the 18 provinces of Angola; (b) land cover map of Angola in 2018 (300 m resolution) adapted the European Space Agency (ESA) Climate Change Initiative Land Cover (CCI-LC) project [70].

\section{Results}

\subsection{Area Burnt in Angola since 2001}

Our results revealed that Angola has been extensively affected by fires every year. On average, ca. $368,300 \mathrm{~km}^{2}$ burn every year since 2001 , corresponding to $30 \%$ of the country's area. The highest values of burnt area were recorded between 2003 and 2005, with more than 400,000 km² burnt each year, and the lowest value was 315,580 $\mathrm{km}^{2}$ in 2018 (Figure 3a). 

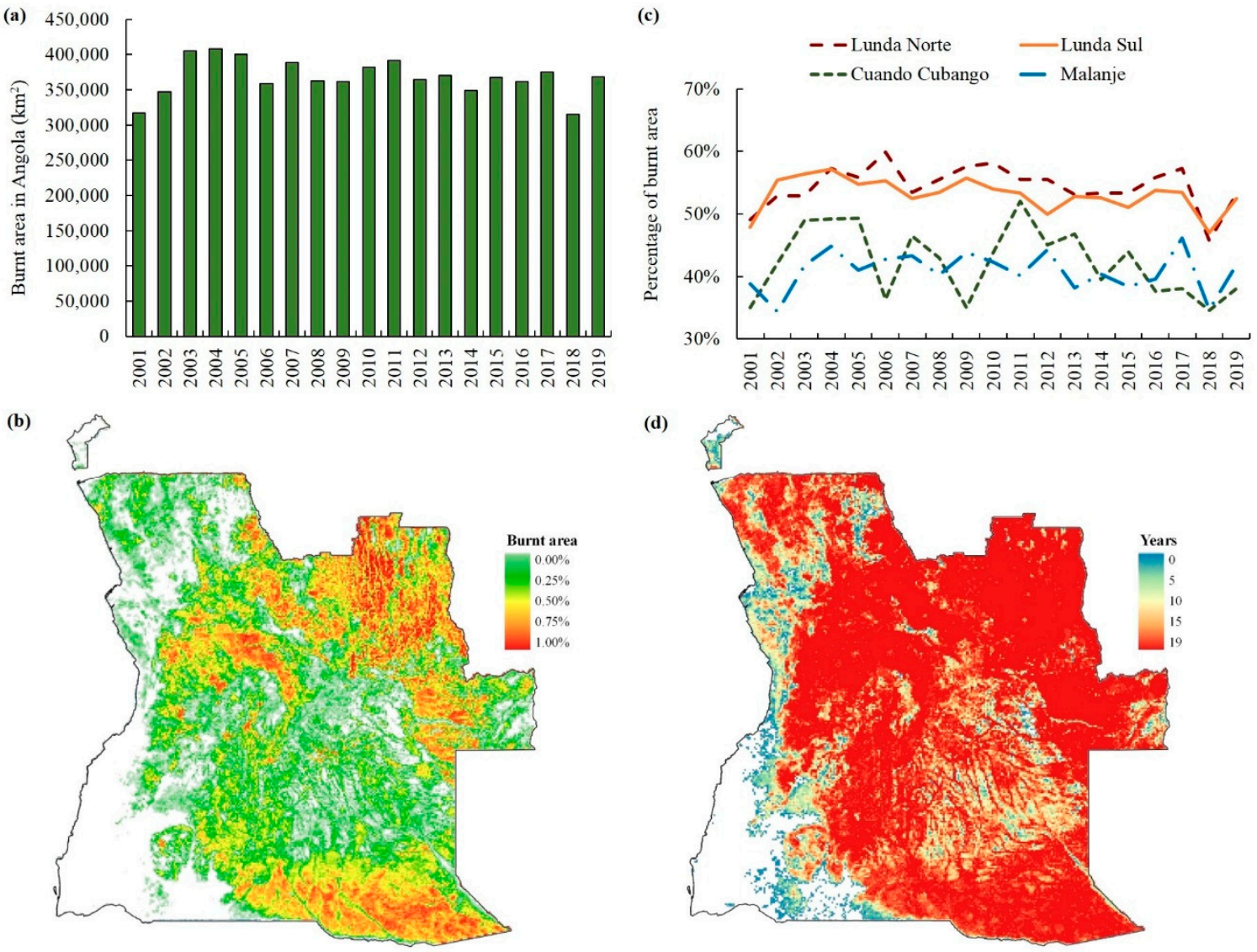

Figure 3. Burnt area in Angola, from 2001 to 2019: (a) Absolute burnt area $\left(\mathrm{km}^{2}\right)$ per year; (b) map of the mean annual fraction of burnt area in each cell (5 km resolution); (c) percentage of the area burnt in the four provinces with the highest values; (d) map of the number of years when each cell was completely or partially burnt since 2001 (5 km resolution).

The northeast and southeast regions of Angola presented the highest percentage of annual burnt area per cell (Figure 3b). The provinces with the largest annual burnt areas were Lunda Norte (54\%, ca. $\left.58,840 \mathrm{~km}^{2}\right)$, Lunda Sul (53\%, ca. 41,375 km²), Cuando Cubango (42\%, ca. $\left.84,455 \mathrm{~km}^{2}\right)$, and Malanje $(41 \%$, ca. 33,586 km²) (Figure 3c, Table S1). Among them, Cuando Cubango showed the highest variations over consecutive years. The most affected municipalities were Lubalo, Cuilo, and Lucapa in Lunda Norte; Saurimo and Muconda in Lunda Sul; Dirico and Rivungo in Cuando Cubango; and Luquenbo and Cangandala in Malanje. Intermediate values were found in Cuanza Sul, Moxico, Bié, Cunene, Cuanza Norte, Huambo, Zaire, Huíla, Uíge, and Benguela, with 12-30\% of area burnt every year. The provinces of Bengo, Cabinda, Luanda, and Namibe had the lowest values, under $10 \%$. Fire events are recurrent in Angola, except in the arid southwestern region. Figure $3 \mathrm{~d}$ shows the number of years when each cell burnt totally or partially between 2001 and 2019. Since 2001, 64\% of the cells burnt 15 years or more.

\subsection{Spatial Trends of Burnt Area in Angola since 2001}

The results of the contextual Mann-Kendall test highlights large areas of significant increasing and decreasing trends in the burnt area of Angola. Figure 4 shows the results of this test, where the red cells represent increasing trends (positive $Z$ value) and green cells represent decreasing trends (negative $Z$ values). The significant areas with a confidence level of $95 \%$ are outlined with a black line. The Mann-Kendall test was also performed (Figure S1), but the contextual Mann-Kendall test (Figure 4) performed better in creating larger and more homogenous clusters of cells corresponding to significant areas. 


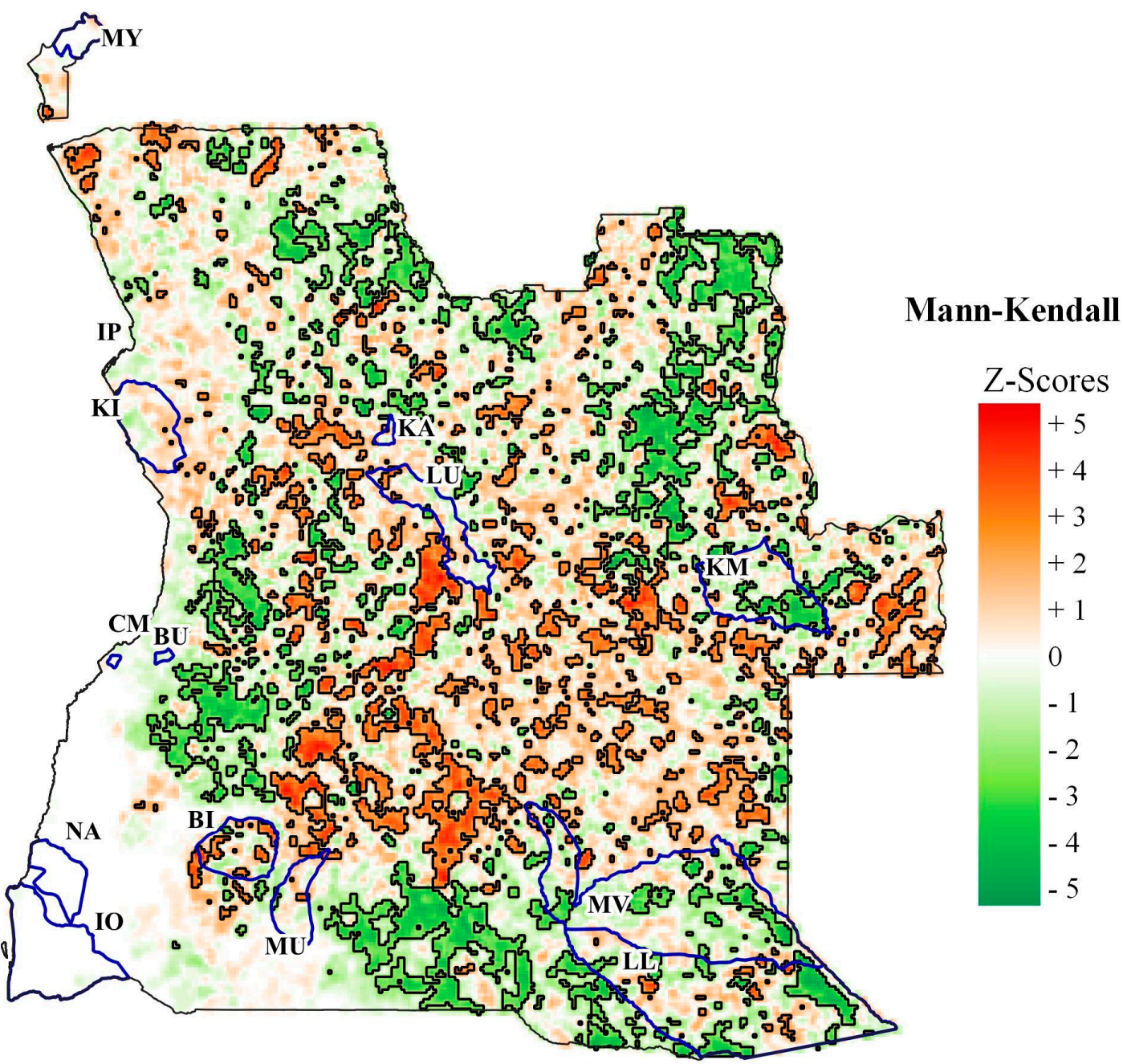

Figure 4. Trends of the annual burnt area in Angola for the 2001-2019 period, based on the contextual Mann-Kendall test. The positive z-scores correspond to areas of increasing trends of burnt area, while the negative z-scores correspond to decreasing trends. The significant areas (with a confidence level of 95\%) were outlined with black lines. Protected areas are indicated with blue outlines: BI, Bicuar; BU, Búfalo; KA, Cangandala; CM, Chimalavera; IO, Iona; IP, Ilheu dos Pássaros; KM, Cameia; KI, Quiçama; LL, Luengue-Luiana; LU, Luando; MV, Mavinga; MU, Mupa; MY, Maiombe; NA, Namibe.

We detected significant areas of increasing trends in ca. $119,410 \mathrm{~km}^{2}(10 \%$ of the country's area), mainly in the central region of the country. With more than $9400 \mathrm{~km}^{2}$, the single largest area is located in the north of the Cuando Cubango province, and the second largest area, with ca. $4330 \mathrm{~km}^{2}$, is found in Bié. The provinces with the most extensive areas of significant positive trends are Moxico $(34,731$ $\left.\mathrm{km}^{2}\right)$, Cuando Cubango $\left(18,628 \mathrm{~km}^{2}\right)$, Bié $\left(15,830 \mathrm{~km}^{2}\right)$, and Huíla $\left(12,658 \mathrm{~km}^{2}\right)$ (Figure 5, Table 1). Significant areas of decreasing trends was detected in ca. $154,240 \mathrm{~km}^{2}$ (12\% of the country's area), spread all across Angola, except in its central region. The single largest area has more than $21,800 \mathrm{~km}^{2}$ and covers part of the Cuando Cubango and Cunene provinces; the second largest single area has approximately $14,000 \mathrm{~km}^{2}$ and is located in Lunda Sul. The provinces with the most extensive areas of significant negative trends are Cuando Cubango $\left(34,584 \mathrm{~km}^{2}\right)$, Lunda Sul $\left(21,049 \mathrm{~km}^{2}\right)$, and Lunda Norte $\left(19,353 \mathrm{~km}^{2}\right)$ (Figure 5, Table 1). 


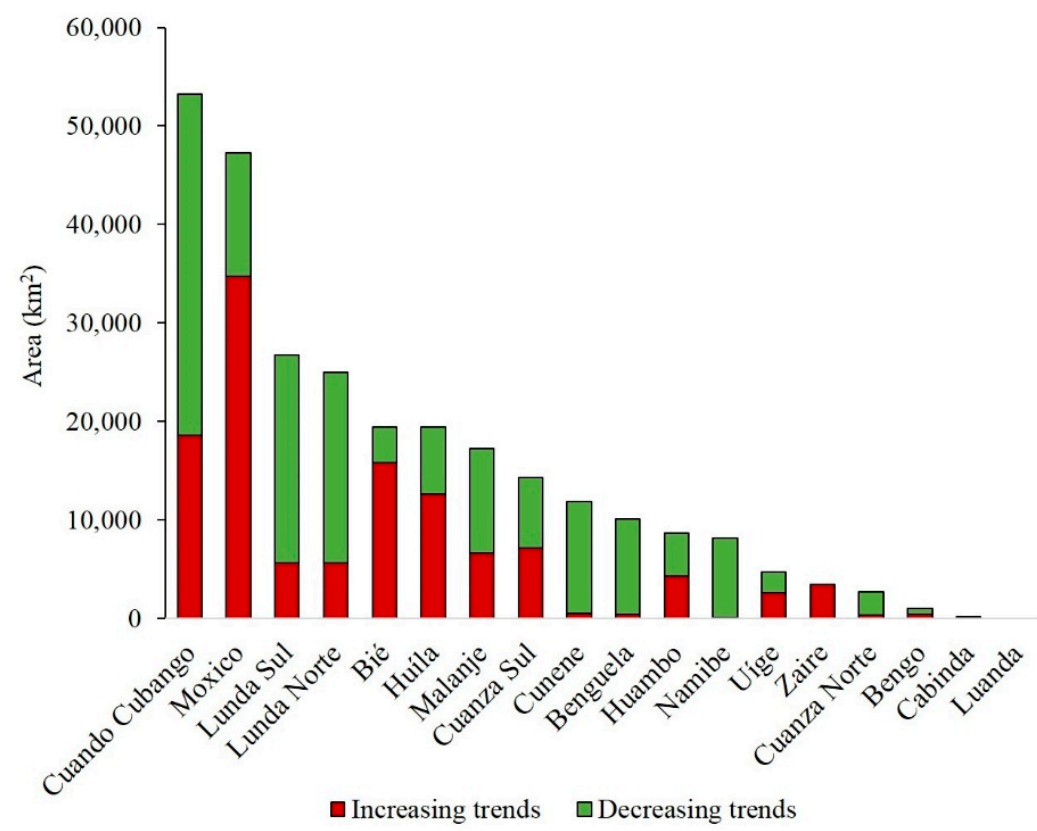

Figure 5. Areas of significant increasing and decreasing trends in Angolan provinces.

Table 1. Area and proportion of increasing and decreasing significant trends of annual burnt area in Angolan provinces, WWF ecoregions, and protected areas, from 2001 to 2019.

\begin{tabular}{|c|c|c|c|c|c|}
\hline \multirow{2}{*}{ Provinces } & \multirow{2}{*}{$\begin{array}{c}\text { Total Area } \\
\left(\mathrm{km}^{2}\right)\end{array}$} & \multicolumn{2}{|c|}{ Area of Decreasing Trend } & \multicolumn{2}{|c|}{ Area of Increasing Trend } \\
\hline & & $\left(\mathrm{km}^{2}\right)$ & $(\%)$ & $\left(\mathrm{km}^{2}\right)$ & $(\%)$ \\
\hline Bengo & 34,363 & 579 & 1.7 & 425 & 1.2 \\
\hline Benguela & 39,509 & 9689 & 24.5 & 459 & 1.2 \\
\hline Bié & 72,048 & 3625 & 5.0 & 15,830 & 22.0 \\
\hline Cabinda & 7119 & 0 & 0.0 & 188 & 2.6 \\
\hline Cuando Cubango & 199,483 & 34,581 & 17.3 & 18,628 & 9.3 \\
\hline Cuanza Norte & 23,823 & 2301 & 9.7 & 381 & 1.6 \\
\hline Cuanza Sul & 55,257 & 7196 & 13.0 & 7149 & 12.9 \\
\hline Cunene & 77,259 & 11,347 & 14.7 & 545 & 0.7 \\
\hline Huambo & 33,133 & 4391 & 13.3 & 4303 & 13.0 \\
\hline Huíla & 78,684 & 6769 & 8.6 & 12,658 & 16.1 \\
\hline Luanda & 2447 & 0 & 0.0 & 0 & 0.0 \\
\hline Lunda Norte & 107,973 & 19,353 & 17.9 & 5639 & 5.2 \\
\hline Lunda Sul & 77,927 & 21,049 & 27.0 & 5680 & 7.3 \\
\hline Malanje & 82,163 & 10,645 & 13.0 & 6641 & 8.1 \\
\hline Moxico & 199,986 & 12,506 & 6.3 & 34,731 & 17.4 \\
\hline Namibe & 57,911 & 8100 & 14.0 & 82 & 0.1 \\
\hline Uíge & 62,005 & 2102 & 3.4 & 2610 & 4.2 \\
\hline Zaire & 36,590 & & 0.0 & 3461 & 9.5 \\
\hline \multicolumn{6}{|l|}{ WWF ecoregions } \\
\hline Angolan Miombo woodlands & 628,703 & 64,488 & 10.3 & 86,310 & 13.7 \\
\hline Angolan montane forest-grassland mosaic & 25,419 & 8251 & 32.5 & 1172 & 4.6 \\
\hline Angolan mopane woodlands & 51,064 & 1344 & 2.6 & 1045 & 2.0 \\
\hline Angolan scarp savanna and woodlands & 73,947 & 3375 & 4.6 & 2552 & 3.5 \\
\hline Atlantic Equatorial coastal forests & 2534 & 0 & 0.0 & 0 & 0.0 \\
\hline Central African mangroves & 1240 & 0 & 0.0 & 326 & 26.3 \\
\hline Central Zambezian Miombo woodlands & 40,648 & 1769 & 4.4 & 6633 & 16.3 \\
\hline Kaokoveld desert & 20,590 & 0 & 0.0 & 0 & 0.0 \\
\hline Namibian savanna woodlands & 33,491 & 0 & 0.0 & 0 & 0.0 \\
\hline Southern Congolian forest-savanna mosaic & 58,558 & 18,693 & 31.9 & 3208 & 5.5 \\
\hline Western Congolian forest-savanna mosaic & 168,864 & 23,118 & 13.7 & 9698 & 5.7 \\
\hline Western Zambezian grasslands & 4606 & 133 & 2.9 & 1134 & 24.6 \\
\hline Zambezian Baikiaea woodlands & 131,010 & 32,382 & 24.7 & 6559 & 5.0 \\
\hline Zambezian Cryptosepalum dry forests & 3085 & 0 & 0.0 & 776 & 25.1 \\
\hline Zambezian flooded grasslands & 3197 & 681 & 21.3 & 0 & 0.0 \\
\hline
\end{tabular}


Table 1. Cont.

\begin{tabular}{|c|c|c|c|c|c|}
\hline \multirow{2}{*}{ Provinces } & \multirow{2}{*}{$\begin{array}{c}\text { Total Area } \\
\left(\mathbf{k m}^{2}\right)\end{array}$} & \multicolumn{2}{|c|}{ Area of Decreasing Trend } & \multicolumn{2}{|c|}{ Area of Increasing Trend } \\
\hline & & $\left(\mathrm{km}^{2}\right)$ & $(\%)$ & $\left(\mathrm{km}^{2}\right)$ & $(\%)$ \\
\hline \multicolumn{6}{|l|}{ Protected Areas } \\
\hline Bicuar National Park & 7728 & 162 & 2.1 & 1809 & 23.4 \\
\hline Bufalo Partial Reserve & 332 & 0 & 0.0 & 0 & 0.0 \\
\hline Chimalavera Natural Regional Park & 214 & 0 & 0.0 & 0 & 0.0 \\
\hline Ilha dos Pássaros Integral Nature Reserve & 0 & 0 & 0.0 & 0 & 0.0 \\
\hline Iona National Park & 15,264 & 0 & 0.0 & 0 & 0.0 \\
\hline Cameia National Park & 14,185 & 3918 & 27.6 & 161 & 1.1 \\
\hline Cangandala National Park & 642 & 0 & 0.0 & 33 & 5.1 \\
\hline Quiçama National Park & 8597 & 0 & 0.0 & 42 & 0.5 \\
\hline Luando Integral Nature Reserve & 8737 & 48 & 0.5 & 769 & 8.8 \\
\hline
\end{tabular}

\subsection{Burnt Area Trends According to WWF Ecoregions, Protected Areas, and Land Cover}

Our results revealed a very uneven distribution of burnt area trends across WWF ecoregions (Figure 6a, Figure S2, and Table 1). Central African mangroves and Zambezian Cryptosepalum dry forests are among the smallest ecoregions occurring in Angola, but they displayed the highest percentage of increasing trends, and no significant decreasing trends. Western Zambezian grasslands, Central Zambezian Miombo woodlands, and Angolan Miombo woodlands also showed very high percentages of increasing trends $(25 \%, 16 \%$, and $14 \%$, respectively) and much lower percentages of decreasing trends (3\%, $4 \%$, and $10 \%$, respectively). The Angolan Miombo woodlands is the largest ecoregion (more than $628,000 \mathrm{~km}^{2}$ ), covering the central region of Angola.

The high percentage of decreasing trends was found in the Angolan Montane forest-grassland mosaic (32\%), the Southern Congolian forest-savanna mosaic (32\%), the Zambezian Baikiaea woodlands $(25 \%)$, the Zambezian flooded grasslands (21\%), and the Western Congolian forest-savanna mosaic $(14 \%)$. The Namibian Savanna woodlands, Kaokoveld desert, and Atlantic Equatorial coastal forests exhibited no significant trends of burnt area.

In protected areas, burning trends are mainly negative. Our results revealed areas of decreasing trends in five national parks, totaling ca. $19,560 \mathrm{~km}^{2}$, which represents $12 \%$ of the national protected area (Figure 4, Table 1). Cameia has the highest percentage of decreasing trends $\left(28 \%, 3918 \mathrm{~km}^{2}\right)$, followed by Luengue-Luiana $\left(18 \%, 7811 \mathrm{~km}^{2}\right)$ and Mavinga $\left(17 \%, 7466 \mathrm{~km}^{2}\right)$ national parks (Figure $6 \mathrm{~b}$ ). The area of increasing trends was ca. $5710 \mathrm{~km}^{2}$, corresponding to $4 \%$ of the global protected area. It was detected in eight protected areas and the highest proportion was found in Bicuar National Park $\left(23 \%\right.$ of the park's area, $\left.1809 \mathrm{~km}^{2}\right)$ (Figure $6 \mathrm{~b}$, Table 1). Luando reserve $\left(9 \%, 769 \mathrm{~km}^{2}\right)$, Cangandala $(5 \%$, $\left.33 \mathrm{~km}^{2}\right)$, Mupa $\left(5 \%, 240 \mathrm{~km}^{2}\right)$, and Luengue-Luiana $\left(4 \%, 1949 \mathrm{~km}^{2}\right)$ national parks also have important fractions of increasing trends. Some national parks, such as Namibe, Iona, and Maiombe, showed no significant trend.

Concerning the land cover, Angola is covered mainly by natural vegetation as forest, shrubland, and grassland. In 2018, forest (including broadleaved, deciduous, evergreen, and flooded tree classes) was found in 59\% of the country's area, shrubland in 18\% and grassland in 12\% (Figure 7a). Cropland was identified in ca. $48,900 \mathrm{~km}^{2}$, representing only $4 \%$ of the territory. Comparing the composition of the areas included in the significant clusters, clusters with increasing trends presented a much higher fraction of forest classes $(80 \%)$ than clusters with decreasing trends (55\%). In clusters with decreasing trends, the proportions of grassland and shrubland were much higher $(20 \%$ and $19 \%$, respectively) than in the increasing ones ( $4 \%$ and $10 \%$, respectively) (Figure $7 \mathrm{a}$ and Figure S3). 
(a)

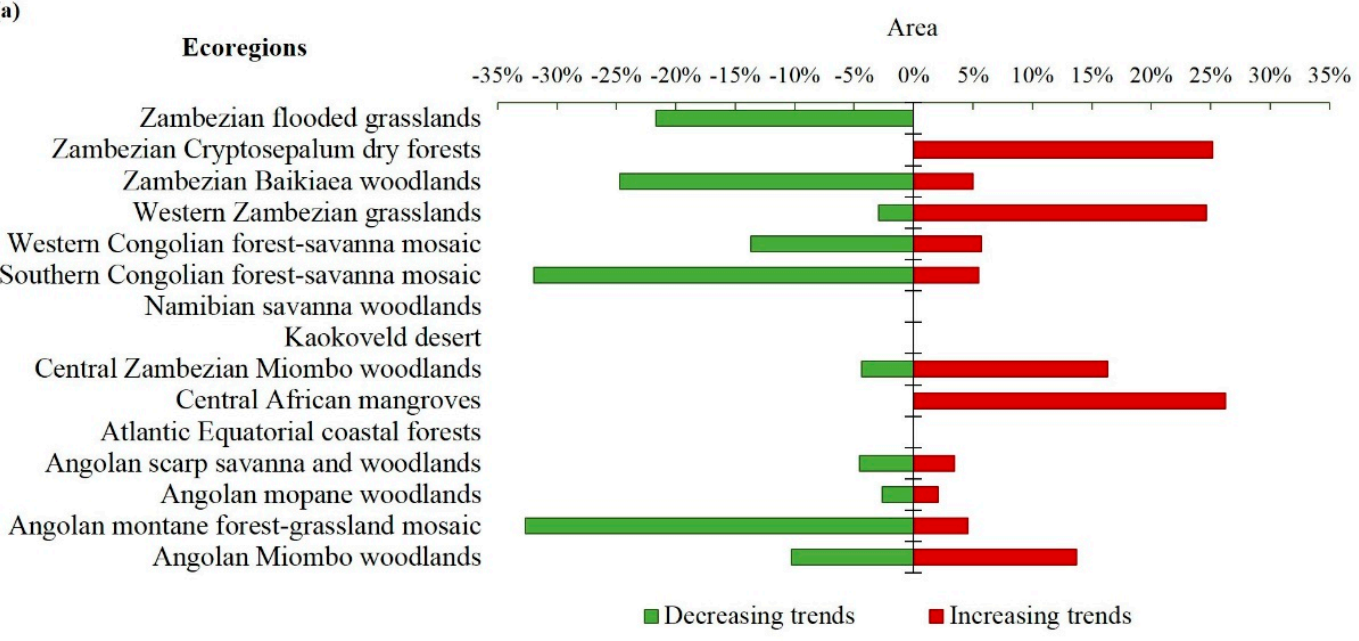

(b)

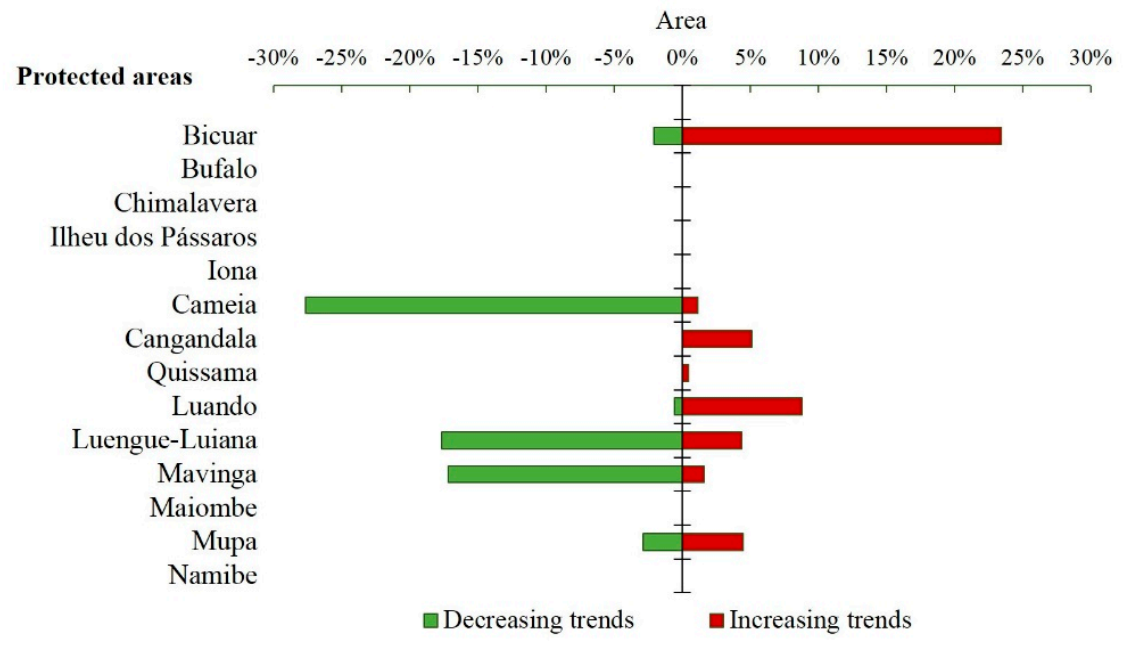

Figure 6. Areas (\%) of significant increasing and decreasing trends: (a) in WWF ecoregions; (b) in protected areas.

Areas with significant increasing and decreasing trends show similar patterns of land cover changes since 2002 (Table 2), occurring a global decrease in natural vegetation extent, i.e., grassland, shrubland, and forest, as well as an increase in cropland and urban areas (Figure 7). In significant clusters, forest shows a small increase in area between 2002 and 2006, but after 2006 it decreases and reaches the lowest value in 2018. Shrubland has maintained almost stable since 2010, with a small increase during the last four years in clusters with decreasing trends. Between 2002 and 2018, clusters with increasing trends have lost of $0.04 \%$ of forest, $0.38 \%$ of shrubland, and $1.26 \%$ of grassland, but displayed an increase of cropland ( $8.84 \%$ ). Decreasing trend clusters lost $0.13 \%$ of forest area, $0.40 \%$ of shrubland and $1.19 \%$ of grassland, and has a great increase of cropland by $15.87 \%$ (Figure 8 ). Urban areas represented a small fraction inside the clusters, but they have a great increase, mainly in clusters with decreasing trends. 
(a)

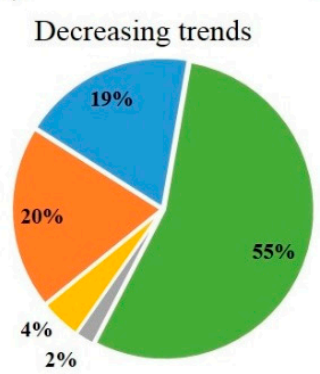

- Cropland " Grassland " Shrubland " Tree cover $(>15 \%) \quad$ " Other

(c)

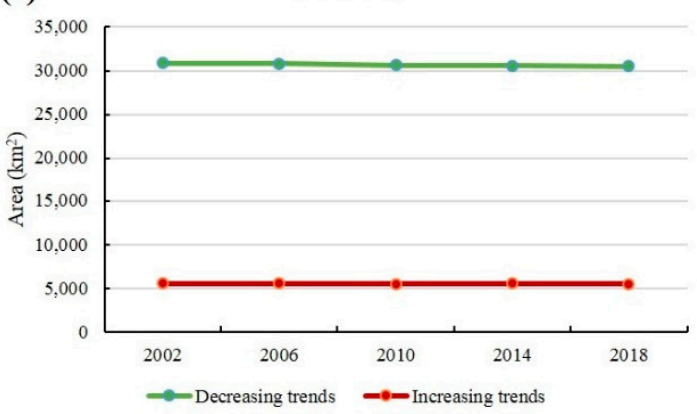

(e)

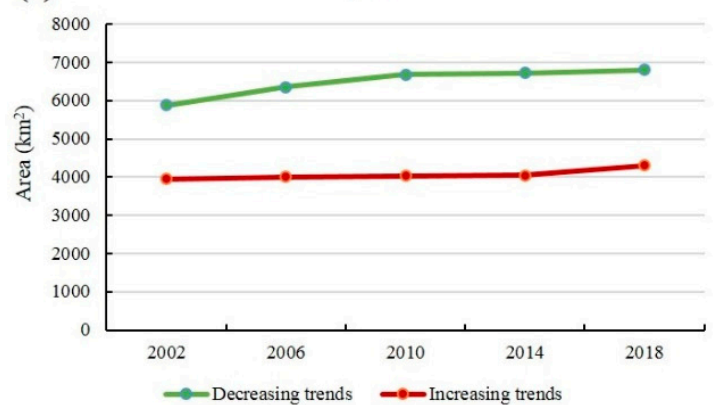

(b)

Forest

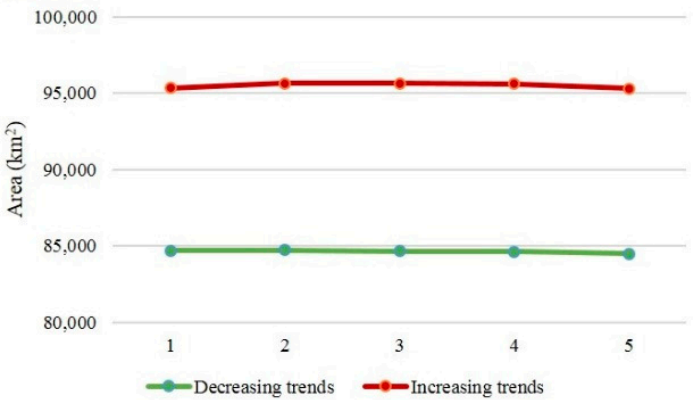

(d)

Shrubland

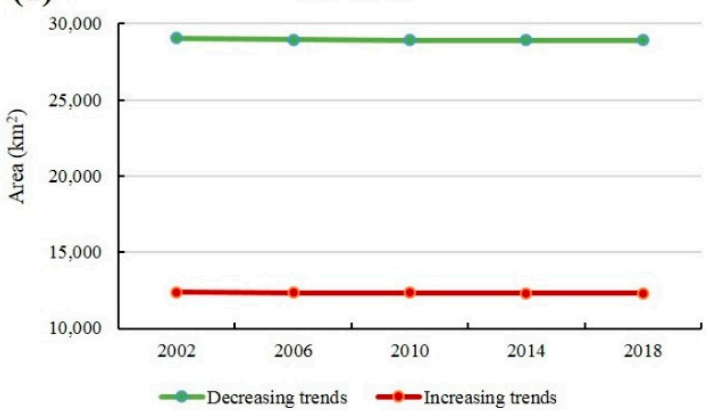

(f)

Urban areas

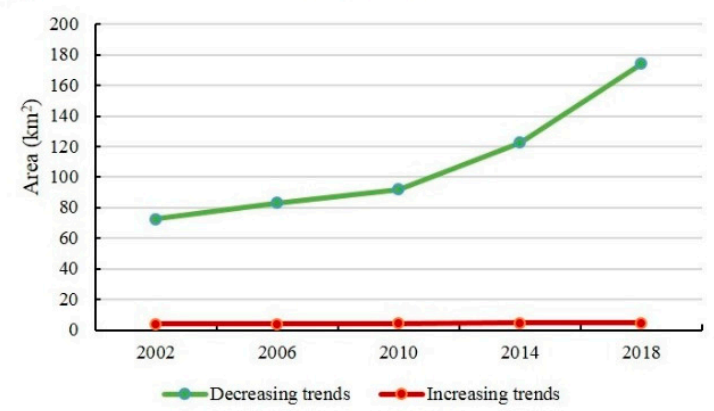

Figure 7. Land cover and the significant trends of burnt areas from 2002 to 2018, in increasing and decreasing trends clusters: (a) Proportions of the main land cover classes in 2018 (the last year for which information is available); (b) area of forest; (c) area of grassland; (d) area of shrubland; (e) area of cropland; (f) area of urban areas.

(a) Area of increasing trends

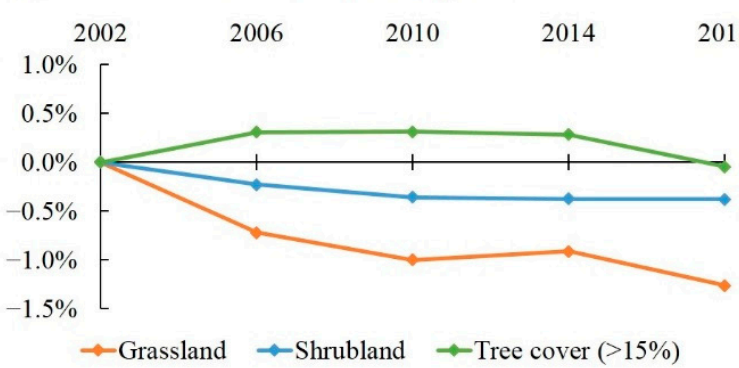

(b)

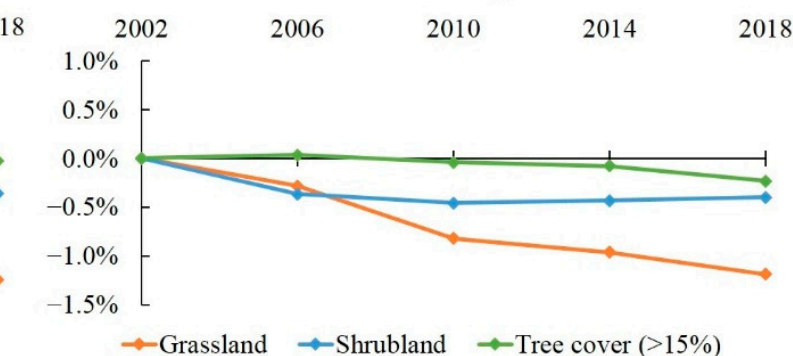

Figure 8. Changes in area of natural land cover classes (grassland, shrubland and forest) since 2002 to 2018, (a) in increasing trends clusters, and (b) in decreasing trend clusters. 
Table 2. Area of land cover classes within the significant clusters of burnt area trends, in 2002, 2006, 2010, 2014 , and 2018.

\begin{tabular}{|c|c|c|c|c|c|c|c|c|c|c|c|c|}
\hline \multirow[b]{2}{*}{ Land Cover Class } & \multicolumn{6}{|c|}{ Area of Decreasing Trends } & \multicolumn{6}{|c|}{ Area of Increasing Trends } \\
\hline & $\begin{array}{c}2002 \\
\left(\mathrm{~km}^{2}\right)\end{array}$ & $\begin{array}{c}2006 \\
\left(\mathrm{~km}^{2}\right)\end{array}$ & $\begin{array}{l}2010 \\
\left(\mathrm{~km}^{2}\right)\end{array}$ & $\begin{array}{c}2014 \\
\left(\mathrm{~km}^{2}\right)\end{array}$ & $\begin{array}{l}2018 \\
\left(\mathrm{~km}^{2}\right)\end{array}$ & $\begin{array}{l}\text { Change 2001- } \\
2018\left(\mathrm{~km}^{2}\right)\end{array}$ & $\begin{array}{c}2002 \\
\left(\mathrm{~km}^{2}\right)\end{array}$ & $\begin{array}{c}2006 \\
\left(\mathrm{~km}^{2}\right)\end{array}$ & $\begin{array}{l}2010 \\
\left(\mathrm{~km}^{2}\right)\end{array}$ & $\begin{array}{c}2014 \\
\left(\mathrm{~km}^{2}\right)\end{array}$ & $\begin{array}{c}2018 \\
\left(\mathrm{~km}^{2}\right)\end{array}$ & $\begin{array}{l}\text { Change 2001- } \\
2018\left(\mathrm{~km}^{2}\right)\end{array}$ \\
\hline Bare areas & 0 & 0 & 0 & 0 & 0 & 0 & 2 & 2 & 2 & 2 & 2 & 0 \\
\hline Cropland, irrigated, or post-flooding & 2 & 2 & 2 & 2 & 3 & 2 & 2 & 2 & 2 & 2 & 3 & 1 \\
\hline Cropland, rainfed & 4153 & 4425 & 4581 & 4606 & 4656 & 503 & 2203 & 2239 & 2251 & 2251 & 2349 & 146 \\
\hline Grassland & 30,162 & 30,081 & 29,904 & 29,859 & 29,795 & -366 & 4938 & 4939 & 4928 & 4932 & 4942 & 4 \\
\hline $\begin{array}{l}\text { Mosaic cropland }(>50 \%) / \text { natural vegetation } \\
\text { (tree, shrub, herbaceous cover) }(<50 \%)\end{array}$ & 1720 & 1925 & 2094 & 2111 & 2148 & 428 & 1746 & 1760 & 1777 & 1792 & 1948 & 202 \\
\hline $\begin{array}{l}\text { Mosaic herbaceous cover }(>50 \%) / \text { tree and } \\
\operatorname{shrub}(<50 \%)\end{array}$ & 706 & 701 & 710 & 711 & 705 & -1 & 621 & 580 & 575 & 576 & 547 & -74 \\
\hline $\begin{array}{l}\text { Mosaic natural vegetation (tree, shrub, } \\
\text { herbaceous cover) }(>50 \%) / \text { cropland }(<50 \%)\end{array}$ & 1759 & 1483 & 1382 & 1379 & 1394 & -365 & 1039 & 693 & 673 & 659 & 684 & -355 \\
\hline $\begin{array}{l}\text { Mosaic tree and shrub }(>50 \%) / \text { herbaceous } \\
\text { cover }(<50 \%)\end{array}$ & 1054 & 1008 & 1015 & 1015 & 1032 & -22 & 603 & 620 & 632 & 653 & 682 & 78 \\
\hline $\begin{array}{l}\text { Shrub or herbaceous cover, flooded, } \\
\text { fresh/saline/brackish water }\end{array}$ & 467 & 471 & 484 & 481 & 497 & 30 & 441 & 440 & 446 & 447 & 458 & 17 \\
\hline Shrubland & 29,043 & 28,936 & 28,910 & 28,916 & 28,927 & -116 & 12,364 & 12,336 & 12,320 & 12,318 & 12,317 & -47 \\
\hline $\begin{array}{l}\text { Sparse vegetation (tree, shrub, herbaceous } \\
\text { cover) }(<15 \%)\end{array}$ & 83 & 83 & 83 & 83 & 83 & 0 & 0 & 0 & 0 & 0 & 0 & 0 \\
\hline $\begin{array}{l}\text { Tree cover, broadleaved, deciduous, closed to } \\
\text { open }(>15 \%)\end{array}$ & 82,910 & 82,938 & 82,870 & 82,837 & 82,696 & -214 & 94,565 & 94,827 & 94,829 & 94,801 & 94,493 & -72 \\
\hline $\begin{array}{l}\text { Tree cover, broadleaved, evergreen, closed to } \\
\text { open }(>15 \%)\end{array}$ & 1753 & 1753 & 1756 & 1758 & 1770 & 17 & 762 & 789 & 788 & 790 & 784 & 22 \\
\hline Tree cover, flooded, fresh, or brackish water & 51 & 52 & 53 & 52 & 52 & 1 & 8 & 12 & 13 & 13 & 13 & 5 \\
\hline Tree cover, flooded, saline water & 0 & 0 & 0 & 0 & 0 & 0 & 10 & 13 & 13 & 13 & 14 & 4 \\
\hline Urban areas & 73 & 83 & 92 & 123 & 174 & 101 & 4 & 4 & 4 & 5 & 5 & 1 \\
\hline
\end{tabular}




\section{Discussion}

\subsection{Trends of Annual Burnt Area in Angolan Provinces and Ecoregions}

This study presents a spatial and temporal analysis of the area burnt in Angola based on MODIS satellite images collected from 2001 to 2019, which allows us to assess the main trends over the years. Our results unveiled new information about fire in Angola, revealing the main areas of increasing and decreasing trends of the annual burnt area. There are several studies on fire regimes and dynamics at the global scale or focused in southern Africa (e.g., [17,18,42,77,78]); however, this is the first study on fire trends carried out specifically in Angola and focused on its ecosystems and protected areas. This country encompasses unique habitats and species, and is possibly one of the least documented biodiversity hotspot areas in the world [79]. However, with continued population growth and lack of financial support, subsistence agriculture and human pressure on the land will continue to increase, putting high pressure on natural resources $[19,34,51]$ and endangering the conservation of the Angolan natural heritage [37,47].

The highest values of burnt area were recorded between 2003 and 2005, which may be a consequence of the end of the civil war. During the civil war, ca. one million people were killed and over four million people displaced. Moreover, there was a massive migration from rural communities to the cities and fields were abandoned $[80,81]$. When the war ended, some displaced people returned to rural areas and burnt natural vegetation to clear land for agriculture.

The largest burnt areas and the highest frequency of fire were found in grasslands and savannas of Lunda Norte, Lunda Sul, and Malanje (northeast Angola), as well as in open savannas of Cuando Cubango (southeast Angola). This agrees with previous studies that recognized these regions as the most affected by fires in Angola [15,17,23,77]. However, these provinces presented small areas of increasing trends and the largest clusters of decreasing trends of burnt area, suggesting a possible decrease in fire extent and/or frequency in the coming years, if the current trends are maintained. Lunda Norte and Lunda Sul are formed mainly by vast plains drained by the tributaries of the Cassai-Congo Basin [46]. According to the Köppen-Geiger climatic classification, the climate is humid tropical and tropical savanna, with hot and humid summers, and warm and dry winters [82]. The population density and the practice of agriculture are very low, but the wind plays an important role in the occurrence of fires, drying the grasslands [49,83]. Cuando Cubango is composed mainly of Kalahari sands, as it is a vast plain with slow flowing rivers. The climate is humid subtropical in the north and hot semi-arid in the south, with a low average annual rainfall, ranging from 1000 to $600 \mathrm{~mm}[46,82]$. The population density is low in this region but more than half of the people work in agricultural activities [49]. Malanje has a similar pattern, with low population density but high intensity of agricultural activities [4]. This province includes a plateau in its central region, with elevation from 1000 to $1250 \mathrm{~m}$, and the climate is tropical savanna [46,82].

The main areas of increasing trends were found in central Angola. This region includes Cuanza Sul, Bié, Huambo, Moxico, and Huíla provinces, and consists mainly of Angolan Miombo woodlands. Moxico is located in central-eastern Angola, the mean annual rainfall ranges from 900 to $1300 \mathrm{~mm}$ and is dominated by a humid subtropical climate. Cuanza Sul, Bié, Huambo, and Huíla are located in the extensive region of the ancient plateau, characterized by high levels of annual precipitation in the central zone, reaching $1300 \mathrm{~mm}$ in the province of Huambo. [46,49,82]. These provinces are dominated by tropical savanna, humid subtropical, and oceanic climates [82]. Currently, they have a very high population density and a high fraction of families working in agriculture. The Angolan Miombo woodlands is an ecoregion almost exclusive to Angola, differing from other savannas and forests in its high abundance of trees of the Leguminosae family, specifically, Brachystegia, Julbernardia, and Isoberlinia $[72,84]$. Several authors recognized fire as one of the most important ecological factors in Miombo, preserving the balance between grasses and trees [11,85]. Most plant species of Miombo show some degree of fire resistance, yet they cannot survive intense and recurrent fires [11]. The natural cause of Miombo fires is mainly thunderstorms in the early rainy season, but most fires are caused by 
human action and occur during the dry and hot season [11], when the grass fuel is drier, resulting in more intense, damaging fires. A continuous increase in burnt area for a long period could represent a serious threat for tree species, transforming Miombo woodlands into open savannas [23].

The Central Zambezian Miombo woodlands should also be a priority for future studies and fire management measures. The ecoregion is found in the eastern province of Moxico and show more than $16 \%$ of the area with significant increasing trends. Both ecoregions, the Angolan Miombo woodlands and the Central Zambezian Miombo woodlands, are included in the regional center of Zambezian endemism (defined by White [86]), housing a high richness and endemism of plant and animal species [72]. Fire is an integral part of the Miombo ecology, but changes in fire regimes, such as the increase in frequency or severity, can result in drastic landscape changes, reducing or removing some species. Zambezian Cryptosepalum dry forests, Western Zambezian grasslands, and Central African mangroves showed the highest percentage of increasing trends. However, these ecoregions are very little represented in the country, with less than $5000 \mathrm{~km}^{2}$ each, and these results cannot be considered representative. Mangroves are present in a small area on the bank of the Congo River, surrounded by extensive areas of Angolan scrap savanna and woodlands. The cluster of growing trends detected in the mangrove area is shared with an extensive area of scrap savanna, suggesting that it may correspond to a commission error, resulting from the effect of the neighboring cells involved in the determination of trends. The same may be occurring with Zambezian Cryptosepalum dry forests and Western Zambezian grasslands, these ecoregions are surrounding by Angolan and Central Zambezian Miombo woodlands, which has large clusters of significant increasing trends of burnt area in transitional zones.

The WWF ecoregions show very clear patterns of increasing and decreasing trends in the area burnt. The ecoregions represent the original distribution of distinct assemblages of species and communities [20], better distinguishing the structural organization of the landscape than the generic vegetation classes. The definition of fire management measures and laws must be adapted to each ecoregion's characteristics, addressing socioeconomic and ecological problems that restore, protect, and maintain natural habitats.

\subsection{Implications for Vegetation and Land Cover}

The largest clusters of decreasing trends in burnt area are found in the regions most affected by fire events every year, such as Lunda Norte, Lunda Sul, and Cuando-Cubango. These regions have a lower percentage of forest (ca. 55\%) and a large percentage of shrubland $(19 \%)$ and grassland $(20 \%)$, a pattern probably resulting from the recurrent fires identified in these provinces that limit the growth of trees and shrubs. In these clusters, there was also a strong increase in the extent of urban areas, which more than doubled from 2002 to 2018, and of cropland areas, which slowly but continuously has been growing over the years.

On the other hand, the areas of increasing trends are characterized by a large proportion of forest (ca. $80 \%)$ and small fractions of shrubland $(10 \%)$ and grassland $(4 \%)$. These areas also have a relatively high proportion of cropland (4\%), which substantially increased since 2004. In these regions, the continuous increasing trend of the annual burnt area may lead to the conversion of forests and woodlands into grasslands and shrublands. Interestingly, Cuando Cubango is among the provinces that displays more areas of significant positive trends but also more areas of negative trends. This reveals high turnover of burnt areas in the province, possibly resulting in high levels of land cover changes.

Our findings show a reduction in forest cover over the years, which is in agreement with other studies [23,42], confirming that land cover changes in Africa have been dominated by woodland and forest losses. The fires have had severe effects on Angolan woodlands, converting large areas of forest and woodlands into open land [25]. For instance, a study by Palacios et al. [87] reported that $78.4 \%$ of Huambo province was covered by Miombo woodland in 2002, but 13 years later it had dropped to 48.3\%. Similar losses in western Cuando Cubango, eastern Huíla, and eastern Huambo were reported by Schneibel et al. [88], and Mendelsohn and Mendelsohn [89]. However, the rate of forest loss detected 
in this study appears to be much lower than the rate reported by Hansen et al. [30], as reported by Food and Agriculture Organization of the United Nations (FAO) [31,90] and Global Forest Watch [32]. Other studies of land cover change [91,92] have also detected a much lower estimate of total forest area and forest loss when using ESA CCI-LC maps. One possible explanation is the different data sources. FAO collected forest resource data from the member countries [31], using satellite imagery and field surveys in different countries, while Hansen et al. [30] used high spatial resolution satellite data $(30 \mathrm{~m})$ obtained from NASA's Landsat, which allows for the detection of small-scale forest clear cuts. The different fraction of canopy considered in the forest definitions is also a possible cause of the disparity in the results. FAO [31] adopted a definition $>10 \%$ canopy cover, while Global Forest Watch defined $>30 \%$ canopy cover as forest. In our study, forest is defined as areas with $>15 \%$ canopy cover, which does not reflect the decrease in the percentage of tree cover within each area, unless it falls below $15 \%$ of coverage.

The expansion of shifting cultivation practiced by smallholders and the overexploitation for timber, fuelwood, and charcoal are possibly the most important factors driving the rapid loss of Angolan woodlands and forests, as well as their very slow recovery rate [23]. The relative lack of nutrients and moisture in soils forces the farmers to leave their fields and use fire to clear new fields and enrich the soil with nutrients from the ash of the woody biomass [93]. The rate at which the woodlands are cleared and converted into cropland is dependent on the need to feed a growing human population. To reduce the impacts of human activity on fire processes, management strategies should be urgently implemented. These strategies must incorporate the ecological and socio-economic roles of fire, as well as the conservation of Angolan ecosystems [16].

\subsection{Conservation and Management of Protected Areas}

The protected areas system shows a strong impact on the burnt areas, presenting larger clusters of decreasing trends than of increasing trends. For instance, Cameia, Luengue-Luiana, and Mavinga national parks are located in eastern Angola (Moxico and Cuando Cubango provinces) and have the largest areas of decreasing annual burnt area. The decreasing trends detected in these areas may be related to the increase in the number of herbivores after the civil war. For instance, a study carried out in Luiana National Park showed a rapid increase in the numbers of African elephants between 2004 and 2005 [94]. According to Goldammer and Ronde [11], the abundance of mammalian herbivores is an important determinant of fire intensity. When the number of herbivores is high, less fuel is available and fires can affect smaller areas, with lower intensities [11,95].

Bicuar National Park is the most worrying protected areas, with increasing trends in more than $23 \%$ of its area. It is the only protected area of Huila, located in a transition zone between the Angolan Miombo woodlands and the Zambezian Baikiaea woodlands ecoregions. With an area of almost $8000 \mathrm{~km}^{2}$, it consists mainly of riverbanks of the Cunene River, sandy hills, and river valleys with savannah grasslands. It was created in 1938 as a hunting reserve due to the abundance of game species, such as African bush elephant (Loxodonta africana), blue wildebeest (Connochaetes taurinus subsp. taurinus), and eland (Tragelaphus oryx) [96]. The analysis of Luando Integral Nature Reserve also reveals significant increasing trends in ca. $9 \%$ of this area. The status of protected area was acquired in 1955, to conserve the giant sable antelope (Hippotragus niger subsp. variani) [97], including more than $8000 \mathrm{~km}^{2}$ of the Angolan Miombo woodlands.

Angolan protected areas need a real and efficient administration, in addition to integrated biodiversity management plans. In 2006, the National Parks of Quissama, Mupa, Cangandala, Iona, Cameia, and Bicuar were almost completely abandoned, without equipment or supervision [98]. Parts of these protected areas are occupied by human populations that hunt and burn without control, leading to the disappearance of large mammals and converting large areas into agricultural land [78]. However, the Protected Areas system was greatly expanded in 2011 and more resources are being made available for more effective management [46]. The difficulties imposed by limited budgets, scarce 
human resources, and weak technical capacity impose the need to identify priority areas, where the government's conservation resources must be allocated first.

Fires have been the main management tool used in protected areas of the African savanna [95]. During the 20th century, managers of protected areas have considered both the suppression of unwanted fires and ignition of prescribed fires to achieve different goals, such as reducing the putative negative effects of fire on ecosystems, reducing the risk of unplanned fires, improving visibility for game viewing and policing, improving forage quality, and fighting invasive alien species [95,99-101]. Fire managers must decide how, where, and when to apply fires to achieve their goals of management, while also respecting legal constraints. During the 21st century, fire management in Angola will face new challenges imposed by the effects of climate change and a growing human population.

\section{Conclusions}

In this study, we detected spatial and temporal patterns of burnt areas across Angola, which is a crucial step for the definition of conservation priorities and management strategies. The identification of the areas with significant trends is extremely important in tropical areas with low field data available and few human and financial resources, as is the case of Angola. This will allow for efficient distribution of fire management resources and public investment, resulting in improved management of Angolan vegetation.

Understanding the role of climatic and anthropogenic factors on these trends is very important. The overexploitation of forests for the production of timber, firewood, and charcoal also enhances grass development, which in turn promotes more intense fires in the dry season. Effective actions to limit fire events are urgently needed to protect fire-sensitive resources, natural ecosystems, and to reduce carbon emissions to the atmosphere. While most southern African countries have legislation and regulations to use and control fire, these are rarely applied due to enforcement difficulties [11]. Fire control is also difficult because, in Africa, fires occur in thousands of small, dispersed events. Moreover, climate change will bring more frequent and intense droughts to Angola, with strong impacts on water resources, agricultural productivity, and wildfire potential. All of these factors are expected to play an important-negative-role on the trends of burnt areas, land cover change, and biodiversity conservation.

Supplementary Materials: The following are available online at http://www.mdpi.com/1424-2818/12/8/307/s1, Figure S1: Trends of annual burnt area in Angola for the 2001-2019 period, based on Mann-Kendall single-cell analysis. The positive z-scores correspond to areas of increasing trends of burnt area, while the negative z-scores correspond to decreasing trends. The significant areas (with a confidence level of $95 \%$ ) were overlaid with black lines. Protected areas are limited with blue lines: BI, Bicuar; BU, Búfalo; KA, Cangandala; CM, Chimalavera; IO, Iona; IP, Ilheu dos pássaros; KM, Cameia; KI, Quiçama; LL, Luengue-Luiana; LU, Luando; MV, Mavinga; MU, Mupa; MY, Maiombe; NA, Namibe. Figure S2: WWF ecoregions occurring in Angola and the significant cluster of increasing and decreasing trends of annual burnt area detected in 2001- 2019 period, based on the Contextual Mann-Kendall test. Figure S3: Land cover map of Angola in 2018 (300 m resolution), adapted the European Space Agency (ESA) Climate Change Initiative Land Cover (CCI-LC), and the significant cluster of increasing and decreasing trends of annual burnt area detected in 2001-2019 period, based on the contextual Mann-Kendall test. Table S1: Estimated fraction of burnt area per year and the average of the burnt area from 2001 to 2019 in each province.

Author Contributions: Conceptualization, S.C., M.M.R. and J.M.C.P.; methodology, S.C., J.M.N.S. and J.M.C.P.; formal analysis, S.C., V.A., J.M.N.S. and J.M.C.P.; writing-original draft preparation, S.C.; writing-review and editing, M.M.R., R.F., V.A., J.M.N.S. and J.M.C.P. All authors have read and agreed this version of the manuscript.

Funding: This research was funded by Foundation for Science and Technology (FCT) of the Portuguese Government through the grants SFRH/BD/120054/2016 to S.C., UID/AGR/04129/2019 to Linking Landscape, Environment, Agriculture and Food (LEAF), UID/BIA/00329/2019 to Centre for Ecology, Evolution and Environmental Changes (cE3c), UIDB/00239/2020 to Forest Research Centre (CEF).

Conflicts of Interest: The authors declare no conflict of interest. The funders had no role in the design of the study; in the collection, analyses, or interpretation of data; in the writing of the manuscript, or in the decision to publish the results. 


\section{References}

1. He, T.; Lamont, B.B.; Pausas, J.G. Fire as a key driver of earth's biodiversity. Biol. Rev. 2019, 94, $1983-2010$. [CrossRef]

2. Kahiu, M.N.; Hanan, N.P. Fire in sub-Saharan Africa: The fuel, cure and connectivity hypothesis. Glob. Ecol. Biogeogr. 2008, 27, 946-957. [CrossRef]

3. Higgins, S.I.; Bond, W.J.; Trollope, W.S.W. Fire, resprouting and variability: A recipe for grass-tree coexistence in savanna. J. Ecol. 2000, 88, 213-229. [CrossRef]

4. Bond, W.J.; Woodward, F.I.; Midgley, G.F. The global distribution of ecosystems in a world without fire. New Phytol. 2005, 165, 525-538. [CrossRef] [PubMed]

5. Shorrocks, B.; Bates, W. The Biology of African Savannahs; Oxford University Press: New York, NY, USA, 2007.

6. Maurin, O.; Davies, T.J.; Burrows, J.E.; Daru, B.H.; Yessoufou, K.; Muasya, A.M.; van der Bank, M.; Bond, W.J. Savanna fire and the origins of the 'underground forests' of Africa. New Phytol. 2014, 204, 201-214. [CrossRef]

7. Ferreira, L.N.; Vega-Oliveros, D.A.; Zhao, L.; Cardoso, M.F.; Macau, E.E. Global fire season severity analysis and forecasting. Comput. Geosci. 2020, 134, 104339. [CrossRef]

8. Van der Werf, G.R.; Randerson, J.T.; Giglio, L.; Collatz, G.J.; Mu, M.; Kasibhatla, P.S.; Morton, D.C.; DeFries, R.S.; Jin, Y.; van Leeuwen, T.T. Global fire emissions and the contribution of deforestation, savanna, forest, agricultural, and peat fires (1997-2009). Atmos. Chem. Phys. 2010, 10, 11707-11735. [CrossRef]

9. Giglio, L.; Randerson, J.T.; van der Werf, G.R. Analysis of daily, monthly, and annual burned area using the fourth-generation global fire emissions database (GFED4). J. Geophys. Res. 2013, 118, 317-328. [CrossRef]

10. Grégoire, J.M.; Tansey, K.; Silva, J.M.N. The GBA2000 initiative: Developing a global burnt area database from SPOT-VEGETATION imagery. Int. J. Remote Sens. 2003, 24, 1369-1376. [CrossRef]

11. Goldammer, J.G.; De Ronde, C. Wildland fire Management Handbookfor Sub-Sahara Africa; Global Fire Monitoring Center: Freiburg, Germany, 2004.

12. Hodnebrog, Ø.; Myhre, G.; Forster, P.M.; Sillmann, J.; Samset, B.H. Local biomass burning is a dominant cause of the observed precipitation reduction in southern Africa. Nat. Commun. 2016, 7, 1-8. [CrossRef]

13. Schneibel, A.; Stellmes, M.; Röder, A.; Finckh, M.; Revermann, R.; Frantz, D.; Hill, J. Evaluating the trade-off between food and timber resulting from the conversion of Miombo forests to agricultural land in Angola using multi-temporal Landsat data. Sci. Total Environ. 2016, 548, 390-401. [CrossRef] [PubMed]

14. United States Agency for International Development. Angola Biodiversity and Tropical Forests: 118/119 Assessment. Prepared by the Biodiversity Analysis and Technical Support (BATS) Team for the United States Agency for International Development. Available online: https://usaidgems.org/Documents/FAA\&Regs/ FAA118119/Angola2013.pdf (accessed on 6 April 2020).

15. Archibald, S.; Roy, D.P.; van Wilgen, B.W.; Scholes, R.J. What limits fire? An examination of drivers of burnt area in Southern Africa. Glob. Change Biol. 2009, 15, 613-630. [CrossRef]

16. Shlisky, A.; Alencar, A.A.; Nolasco, M.M.; Curran, L.M. Overview: Global fire regime conditions, threats, and opportunities for fire management in the tropics. In Tropical Fire Ecology; Cochrane, M.A., Ed.; Springer-Praxis: Berlin, Germany, 2009; pp. 65-83.

17. Barbosa, P.M.; Stroppiana, D.; Grégoire, J.M.; Pereira, J.M.C. An assessment of vegetation fire in Africa (1981-1991): Burned areas, burned biomass, and atmospheric emissions. Global Biogeochem. Cycles 1999, 13, 933-950. [CrossRef]

18. Archibald, S.; Scholes, R.J.; Roy, D.P.; Roberts, G.; Boschetti, L. Southern African fire regimes as revealed by remote sensing. Int. J. Wildland Fire 2010, 19, 861-878. [CrossRef]

19. Frazão, R.; Catarino, S.; Goyder, D.; Darbyshire, I.; Magalhães, M.F.; Romeiras, M.M. Species richness and distribution of the largest plant radiation of Angola: Euphorbia (Euphorbiaceae). Biodivers. Conserv. 2020, 29, 187-206. [CrossRef]

20. Olson, D.M.; Dinerstein, E.; Wikramanayake, E.D.; Burgess, N.D.; Powell, G.V.N.; Underwood, E.C.; D'amico, J.A.; Itoua, I.; Strand, H.E.; Morrison, J.C.; et al. Terrestrial ecoregions of the world a new map of life on earth a new global map of terrestrial ecoregions provides an innovative tool for conserving biodiversity. Bioscience 2001, 51, 933-938. [CrossRef]

21. Romeiras, M.M.; Figueira, R.; Duarte, M.C.; Beja, P.; Darbyshire, I. Documenting biogeographical patterns of African timber species using herbarium records: A conservation perspective based on native trees from Angola. PLoS ONE 2014, 9, e103403. [CrossRef] 
22. Dwyer, E.; Pinnock, S.; Grégoire, J.M.; Pereira, J.M.C. Global spatial and temporal distribution of vegetation fire as determined from satellite observations. Int. J. Remote Sens. 2020, 21, 1289-1302. [CrossRef]

23. Mendelsohn, J.M. Landscape changes in Angola. In Biodiversity of Angola. Science E Conservation: A Modern Synthesis; Huntley, B.J., Russo, V., Lages, F., Ferrand, N., Eds.; Springer: Cham, Switzerland, 2019; pp. 123-137. [CrossRef]

24. Mishra, N.B.; Mainali, K.P.; Crews, K.A. Modelling spatiotemporal variability in fires in semiarid savannas: A satellite-based assessment around Africa's largest protected area. Int. J. Wildland Fire 2016, 25, 730-741. [CrossRef]

25. Schneibel, A.; Frantz, D.; Röder, A.; Stellmes, M.; Fischer, K.; Hill, J. Using annual landsat time series for the detection of dry forest degradation processes in south-central Angola. Remote Sens. 2017, 9, 905. [CrossRef]

26. De Cauwer, V.; Mertens, J. Impact of fire on the Baikiaea woodlands. In Climate Change and Adaptive Land Management in Southern Africa-Assessments, Changes, Challenges, and Solutions; Revermann, R., Krewenka, K.M., Schmiedel, U., Olwoch, J.M., Helmschrot, J., Jürgens, N., Eds.; Biodiversity \& Ecology, Klaus Hess Publishers: Windhoek, Namibia, 2018; pp. 334-335. [CrossRef]

27. Sankaran, M.; Ratnam, J.; Hanan, N.P. Tree-grass coexistence in savannas revisited-Insights from an examination of assumptions and mechanisms invoked in existing models. Ecol. Lett. 2004, 7, 480-490. [CrossRef]

28. Gignoux, J.; Lahoreau, G.; Julliard, R.; Barot, S. Establishment and early persistence of tree seedlings in an annually burned savanna. J. Ecol. 2009, 97, 484-495. [CrossRef]

29. Stellmes, M.; Frantz, D.; Finckh, M.; Revermann, R. Fire frequency, fire seasonality and fire intensity within the Okavango region derived from MODIS fire products. Biodivers. Ecol. 2013, 5, 351-362. [CrossRef]

30. Hansen, M.C.; Potapov, P.V.; Moore, R.; Hancher, M.; Turubanova, S.A.; Tyukavina, A.; Thau, D.; Stehman, S.V.; Goetz, S.J.; Loveland, T.R.; et al. High-Resolution Global Maps of 21st-Century Forest Cover Change. Science 2013, 342, 850-853. [CrossRef]

31. Food and Agriculture Organization of the United Nations. Global Forest Resources Assessment 2020-Key Findings. Available online: http://www.fao.org/3/CA8753EN/CA8753EN.pdf (accessed on 8 June 2020).

32. Global Forest Watch. Available online: https://www.globalforestwatch.org/map (accessed on 3 March 2020).

33. Graham, P.H.; Vance, C.P. Legumes: Importance and constraints to greater use. Plant Physiol. 2003, 131, 872-877. [CrossRef] [PubMed]

34. Catarino, S.; Duarte, M.C.; Costa, E.; Carrero, P.G.; Romeiras, M.M. Conservation and sustainable use of the medicinal Leguminosae plants from Angola. Peer] 2019, 7, e6736. [CrossRef]

35. Syampungani, S.; Chirwa, P.W.; Akinnifesi, F.K.; Sileshi, G.; Ajayi, O.C. The miombo woodlands at the cross roads: Potential threats, sustainable livelihoods, policy gaps and challenges. Nat. Resour. Forum. 2009, 33, 150-159. [CrossRef]

36. Ribeiro, N.S.; Syampungani, S.; Nangoma, D.; Ribeiro-Barros, A. Miombo Woodlands Research Towards the Sustainable use of Ecosystem Services in Southern Africa. In Biodiversity in Ecosystems-Linking Structure and Function; Lo, Y., Blanco, J.A., Roy, S., Eds.; IntechOpen: London, UK, 2015; pp. 475-491.

37. Jew, E.K.; Dougill, A.J.; Sallu, S.M.; O'Connell, J.; Benton, T.G. Miombo woodland under threat: Consequences for tree diversity and carbon storage. For. Ecol. Manag. 2016, 361, 144-153. [CrossRef]

38. Climate Change 2014: Impacts, Adaptation, and Vulnerability. Part B: Regional Aspects. Fifth Assessment Report of the Intergovernmental Panel on Climate Change. Available online: https:/www.ipcc.ch/site/assets/ uploads/2018/02/WGIIAR5-PartB_FINAL.pdf (accessed on 3 April 2020).

39. Enright, N.J.; Fontaine, J.B.; Bowman, D.M.; Bradstock, R.A.; Williams, R.J. Interval squeeze: Altered fire regimes and demographic responses interact to threaten woody species persistence as climate changes. Front. Ecol. Environ. 2015, 13, 265-272. [CrossRef]

40. Shlisky, A.; Waugh, J.; Gonzalez, P.; Gonzalez, M.; Manta, M.; Santoso, H.; Alvarado, E.; Nuruddin, A.A.; Rodriguez-Trejo, D.A.; Swarty, R.; et al. Fire, Ecosystems and People: Threats and Strategies for Global Biodiversity Conservation. Global Fire Initiative Technical Report 2007-2; The Nature Conservancy: Arlington, VA, USA, 2007.

41. Silva, J.M.N.; Pereira, J.M.C.; Cabral, A.I.; Sá, A.C.L.; Vasconcelos, M.J.P.; Mota, B.; Grégoire, J.M. An estimate of the area burned in southern Africa during the 2000 dry season using SPOT-VEGETATION satellite data. J. Geophys. Res. 2003, 108, 8498. [CrossRef]

42. Grégoire, J.M.; Eva, H.D.; Belward, A.S.; Palumbo, I.; Simonetti, D.; Brink, A. Effect of land-cover change on Africa's burnt area. Int. J. Wildland Fire 2013, 22, 107-120. [CrossRef] 
43. Giglio, L.; van der Werf, G.R.; Randerson, J.T.; Collatz, G.J.; Kasibhatla, P. Global estimation of burned area using MODIS active fire observations. Atmos. Chem. Phys. 2006, 6, 957-974. [CrossRef]

44. Giglio, L.; Boschetti, L.; Roy, D.P.; Humber, M.L.; Justice, C.O. The Collection 6 MODIS burnt area mapping algorithm and product. Remote Sens. Environ. 2018, 217, 72-85. [CrossRef]

45. Roy, D.P.; Boschetti, L. Southern Africa Validation of the MODIS, L3JRC, and GlobCarbon Burned-Area Products. Geosci. Remote 2009, 47, 1032-1044. [CrossRef]

46. Huntley, B.J. Angola in Outline: Physiography, Climate and Patterns of Biodiversity. In Biodiversity of Angola Science E Conservation: A Modern Synthesis; Huntley, B.J., Russo, V., Lages, F., Ferrand, N., Eds.; Springer: Cham, Switzerland, 2019; pp. 15-42. [CrossRef]

47. Ministério do Ambiente de Angola. $5^{\circ}$ Relatório Nacional 2007-2012 Sobre a Implementação da Convenção da Diversidade Biológica em Angola; Direcção Nacional da Biodiversidade, República de Angola: Luanda, Angola, 2014.

48. Huntley, B.J.; Beja, P.; Vaz-Pinto, P.; Russo, V.; Veríssimo, L.; Morais, M. Biodiversity conservation history, protected areas and hotspots. In Biodiversity of Angola. Science E Conservation: A Modern Synthesis; Huntley, B.J., Russo, V., Lages, F., Ferrand, N., Eds.; Springer: Cham, Switzerland, 2019; pp. 495-512. [CrossRef]

49. Instituto Nacional de Estatística. Resultados Preliminares do Recenseamento Geral da População e da Habitação de Angola 2014; Instituto Nacional de Estatística: Luanda, Angola, 2014.

50. Pröpper, M.; Gröngröft, A.; Finckh, M.; Stirn, S.; De Cauwer, V. The Future Okavango: Findings, Scenarios and Recommendations for Action: Research Project Final Synthesis Report 2010-2015; University of Hamburg-Biocentre Klein Flottbek: Hamburg, Germany, 2015.

51. Goyder, D.J.; Gonçalves, F.M.P. The Flora of Angola: Collectors, richness and endemism. In Biodiversity of Angola. Science E Conservation: A Modern Synthesis; Huntley, B.J., Russo, V., Lages, F., Ferrand, N., Eds.; Springer: Cham, Switzerland, 2019; pp. 79-96. [CrossRef]

52. MCD64A1 MODIS/Terra+Aqua Burnt Area Monthly L3 Global 500m SIN Grid V006 [Data set]. NASA EOSDIS Land Processes DAAC. Available online: https://pdaac.usgs.gov/products/mcd64a1v006/ (accessed on 3 February 2020). [CrossRef]

53. Vermote, E.F.; Justice, N.Z.E. Operational atmospheric correction of the MODIS data in the visible to middle infrared: First results. Remote Sens. Environ. 2002, 83, 97-111. [CrossRef]

54. Justice, C.O.; Giglio, L.; Korontzi, S.; Owens, J.; Morisette, J.T.; Roy, D.; Descloitres, J.; Alleaume, S.; Petitcolin, F.; Kaufman, Y. The MODISfire products. Remote Sens. Environ. 2002, 83, 244-262. [CrossRef]

55. Xiong, X.; Chiang, K.; Sun, J.; Barnes, W.L.; Guenther, B.; Salomonson, V.V. NASA EOS Terra and Aqua MODIS on-orbit performance. Adv. Space Res. 2009, 43, 413-422. [CrossRef]

56. Roy, D.P.; Jin, Y.; Lewis, P.E.; Justice, C.O. Prototyping a global algorithm for systematic fire affected area mapping using MODIS time series data. Remote Sens. Environ. 2005, 97, 137-162. [CrossRef]

57. QGIS Development Team. QGIS Geographic Information System. Open Source Geospatial Foundation Project. Available online: http://qgis.osgeo.org (accessed on 24 February 2020).

58. TerrSet 2020, Geospatial Monitoring and Modeling System. Clark Labs. Available online: https://clarklabs. org/wp-content/uploads/2020/05/TerrSet_2020_Brochure-FINAL27163334.pdf (accessed on 5 February 2020).

59. Durbin, J.; Watson, G.S. Testing for serial correlation in least squares regression. Biometrika 1950, 37, 409-428. [CrossRef]

60. Yue, S.; Wang, C.Y. Regional streamflow trend detection with consideration of both temporal and spatial correlation. Int. J. Climatol. 2002, 22, 933-946. [CrossRef]

61. Silva, J.M.N.; Moreno, M.V.; Le Page, Y.; Oom, D.; Bistinas, I.; Pereira, J.M.C. Spatiotemporal trends of area burnt in the Iberian Peninsula, 1975-2013. Reg. Environ. Change 2019, 19, 515-527. [CrossRef]

62. Wang, X.L.L.; Swail, V.R. Changes of extreme wave heights in Northern Hemisphere oceans and related atmospheric circulation regimes. J. Clim. 2001, 14, 2204-2221. [CrossRef]

63. Mann, H.B. Nonparametric tests against trend. Econometrica 1945, 13, 245-259. [CrossRef]

64. Kendall, M.G. Rank Correlation Methods, 2nd ed.; C. Griffin: London, UK, 1975.

65. Neeti, N.; Eastman, J.R. A contextual Mann-Kendall approach for the assessment of trend significance in image time series. Trans. GIS 2011, 15, 599-611. [CrossRef]

66. Chandler, R.E.; Scott, E.M. Statistical Methods for Trend Detection and Analysis in the Environmental Sciences; Wiley: Chichester, UK, 2011. 
67. Theil, H. A rank-invariant method of linear and polynomial regression analysis. I, II, III. Proc. R. Neth. Acad. Arts Sci. 1950, 53, 386-392, 521-525, 1397-1412. [CrossRef]

68. Sen, P.K. Estimates of the regression coefficient based on Kendall's tau. J. Am. Stat. Assoc. 1968, 63, 1379-1389. [CrossRef]

69. Land Cover CCI: Product User Guide Version 2.0. Available online: http://maps.elie.ucl.ac.be/CCI/viewer/ download/ESACCI-LC-Ph2-PUGv2_2.0.pdf (accessed on 2 March 2020).

70. Defourny, P.; Lamarche, C.; Flasse, C. Product User Guide and Specification ICDR Land Cover 2016 and 2017. Version 1.1.1.; ECMWF: Shinfield Park, UK, 2019.

71. Terrestrial Ecoregions of the World. Available online: https://www.worldwildlife.org/publications/terrestrialecoregions-of-the-world (accessed on 3 March 2020).

72. Burgess, N.; Hales, J.A.; Underwood, E.; Dinerstein, E.; Olson, D.; Itoua, I.; Schipper, J.; Rickketts, T.; Newman, K. Terrestrial Ecoregions of Africa and Madagascar: A Conservation Assessment; Island Press: Washington, DC, USA, 2004.

73. Ladle, R.J.; Whittaker, R.J. Conservation Biogeography; Wiley-Blackwell: Oxford, UK, 2011.

74. Rodrigues, P.; Figueira, R.; Vaz Pinto, P.; Araújo, M.B.; Beja, P. A biogeographical regionalization of Angolan mammals. Mamm. Rev. 2015, 45, 103-116. [CrossRef]

75. World Database on Protected Areas. Available online: https://www.protectedplanet.net/c/world-databaseon-protected-areas (accessed on 3 March 2020).

76. Land Cover Classification Gridded Maps from 1992 to Present Derived from Satellite Observations. Available online: https://cds.climate.copernicus.eu/cdsapp\#!/dataset/satellite-land-cover?tab=overview (accessed on 3 March 2020).

77. Andela, N.; van Der Werf, G.R. Recent trends in African fires driven by cropland expansion and El Nino to La Nina transition. Nat. Clim. Chang. 2014, 4, 791-795. [CrossRef]

78. Andela, N.; van der Werf, G.R.; Kaiser, J.W.T.; van Leeuwen, T.; Wooster, M.J.; Lehmann, C.E.R. Biomass burning fuel consumption dynamics in the tropics and subtropics assessed from satellite. Biogeosciences 2016, 13, 3717-3734. [CrossRef]

79. Myers, N.; Mittermeier, R.A.; Mittermeier, C.G.; da Fonseca, G.A.B.; Kent, J. Biodiversity hotspots for conservation priorities. Nature 2000, 403, 853-858. [CrossRef]

80. Carranza, F.; Treakle, J.; Groppo, P. Land, Territorial Development and Family Farming in Angola: A Holistic Approach to Community-based Natural Resource Governanance: The Cases of Bie, Huambo, and Huila Provinces; Food and Agriculture Organization of the United Nations: Rome, Italy, 2014.

81. Huntley, B.J. Wildlife at War in Angola. The Rise and Fall of an African Eden; Protea Book House: Pretoria, South Africa, 2017.

82. Peel, M.C.; Finlayson, B.L.; Mcmahon, T.A. Updated world map of the Köppen-Geiger climate classification. Hydrol. Earth Syst. Sci. 2007, 11, 1633-1644. [CrossRef]

83. Mills, M.S.; Dean, W.R.J.; Town, R. The avifauna of the Lagoa Carumbo area, northeast Angola. Malimbus 2013, 35, 77-92.

84. Maquia, I.; Catarino, S.; Pena, A.R.; Brito, D.R.; Ribeiro, N.; Romeiras, M.M.; Ribeiro-Barros, A.I. Diversification of African Tree Legumes in Miombo-Mopane Woodlands. Plants 2019, 8, 182. [CrossRef] [PubMed]

85. Timberlake, J.; Chidumayo, E. Miombo Ecoregion Vision Report. Occasional Publications in Biodiversity no. 20; Biodiversity Foundation for Africa: Bulawayo, Zimbabwe, 2011.

86. White, F. The Vegetation of Africa; Unesco: Paris, France, 1983.

87. Palacios, G.; Lara-Gomez, M.; Márquez, A.; Vaca, J.L.; Ariza, D.; Lacerda, V.; Navarro-Cerrillo, R.M. Miombo's Cover Change in Huambo Province (2002-2015); SASSCAL Project Proceedinds: Huambo, Angola, 2015.

88. Schneibel, A.; Stellmes, M.; Revermann, R.; Finckh, M. Agricultural expansion during the post-civil war period in southern Angola based on bi-temporal Landsat data. Biodivers. Ecol. 2013, 5, 311-320. [CrossRef]

89. Mendelsohn, J.M.; Mendelsohn, S. Sudoeste de Angola: Um Retrato da Terra e da Vida. South West Angola: A Portrait of Land and Life; Raison: Windhoek, Namibia, 2018.

90. Food and Agriculture Organization of the United Nations. Global Forest Resources Assessment 2010, Main Report. Available online: http://www.fao.org/3/a-i1757e.pdf (accessed on 8 June 2020).

91. Li, W.; Ciais, P.; MacBean, N.; Peng, S.; Defourny, P.; Bontemps, S. Major forest changes and land cover transitions based on plant functional types derived from the ESA CCI Land Cover product. Int. J. Appl. Earth Obs. Geoinf. 2016, 47, 30-39. [CrossRef] 
92. Li, W.; MacBean, N.; Ciais, P.; Defourny, P.; Lamarche, C.; Bontemps, S.; Houghton, R.A.; Peng, S. Gross and net land cover changes in the main plant functional types derived from the annual ESA CCI land cover maps (1992-2015). Earth Syst. Sci. Data 2018, 10, 219-234. [CrossRef]

93. Gonçalves, F.M.; Revermann, R.; Gomes, A.L.; Aidar, M.P.; Finckh, M.; Juergens, N. Tree species diversity and composition of miombo woodlands in south-central Angola: A chronosequence of forest recovery after shifting cultivation. Int. J. For. Res. 2017, 2017, 6202093. [CrossRef]

94. Chase, M.J.; Griffin, C.R. Elephants of south-east Angola in war and peace: Their decline, re-colonization and recent status. Afr. J. Ecol. 2011, 49, 353-361. [CrossRef]

95. Eby, S.L.; Dempewolf, J.; Holdo, R.M.; Metzger, K.L. Fire in the Serengeti ecosystem: History, drivers, and consequences. In Serengeti IV: Sustaining Biodiversity in a Coupled Human-Natural System; de Sinclair, A.R.E., Metzger, K.L., Mduma, S.A.R., Fryxell, J.M., Eds.; The University of Chicago Press: Chicago, IL, USA, 2015.

96. Butler, B.O.; Ceríaco, L.M.; Marques, M.P.; Bandeira, S.; Júlio, T.; Heinicke, M.; Bauer, A.M. Herpetological survey of Huíla Province, Southwest Angola, including first records from Bicuar National Park. Herpetol. Rev. 2019, 50, 225-240.

97. Pinto, P.V. The Giant Sable Antelope: Angola's National Icon. In Biodiversity of Angola. Science E Conservation: A Modern Synthesis; Huntley, B.J., Russo, V., Lages, F., Ferrand, N., Eds.; Springer: Cham, Switzerland, 2019; pp. 471-491. [CrossRef]

98. Ministério do Urbanismo e Ambiente. National Biodiversity Strategy and Action Plan (2007-2012); Ministério do Urbanismo e Ambiente, República de Angola: Luanda, Angola, 2006.

99. Austen, B. The History of Veld Burning in the Wankie National Park, Rhodesia. Proc. Annu. Tall Timbers Fire Ecol. Conf. 1972, 11, 277-296.

100. Venter, F.J.; Naiman, R.J.; Biggs, H.C.; Pienaar, D.J. The evolution of conservation management philosophy: Science, environmental change and social adjustments in Kruger National Park. Ecosystems 2008, 11, 173-192. [CrossRef]

101. te Beest, M.; Cromsigt, J.P.G.M.; Ngobese, J.; Olff, H. Managing invasions at the cost of native habitat? An experimental test of the impact of fire on the invasion of Chromolaena odorata in a South African savanna. Biol. Invasions 2012, 14, 607-618. [CrossRef]

(C) 2020 by the authors. Licensee MDPI, Basel, Switzerland. This article is an open access article distributed under the terms and conditions of the Creative Commons Attribution (CC BY) license (http://creativecommons.org/licenses/by/4.0/). 